\title{
On the importance of indirect banking vulnerabilities in the Eurozone
}

Citation for published version (APA):

Bicu, A. C., \& Candelon, B. (2012). On the importance of indirect banking vulnerabilities in the Eurozone. METEOR, Maastricht University School of Business and Economics. METEOR Research Memorandum No. 033 https://doi.org/10.26481/umamet.2012033

Document status and date:

Published: 01/01/2012

DOI:

10.26481/umamet.2012033

Document Version:

Publisher's PDF, also known as Version of record

\section{Please check the document version of this publication:}

- A submitted manuscript is the version of the article upon submission and before peer-review. There can be important differences between the submitted version and the official published version of record.

People interested in the research are advised to contact the author for the final version of the publication, or visit the DOI to the publisher's website.

- The final author version and the galley proof are versions of the publication after peer review.

- The final published version features the final layout of the paper including the volume, issue and page numbers.

Link to publication

\footnotetext{
General rights rights.

- You may freely distribute the URL identifying the publication in the public portal. please follow below link for the End User Agreement:

www.umlib.nl/taverne-license

Take down policy

If you believe that this document breaches copyright please contact us at:

repository@maastrichtuniversity.nl

providing details and we will investigate your claim.
}

Copyright and moral rights for the publications made accessible in the public portal are retained by the authors and/or other copyright owners and it is a condition of accessing publications that users recognise and abide by the legal requirements associated with these

- Users may download and print one copy of any publication from the public portal for the purpose of private study or research.

- You may not further distribute the material or use it for any profit-making activity or commercial gain

If the publication is distributed under the terms of Article $25 \mathrm{fa}$ of the Dutch Copyright Act, indicated by the "Taverne" license above, 


\section{Maastricht University}

Andreea Bicu, Bertrand Candelon

On the importance of indirect banking vulnerabilities in the Eurozone

$\mathrm{RM} / 12 / 033$

\section{METEOR}

Maastricht University School of Business and Economics

Maastricht Research School of Economics

of Technology and Organization

P.O. Box 616

NL - 6200 MD Maastricht

The Netherlands 


\title{
On the importance of indirect banking vulnerabilities in the Eurozone
}

\author{
Andreea Bicu* and Bertrand Candelon ${ }^{\dagger}$
}

June 20, 2012

\begin{abstract}
This paper investigates banking and sovereign distress in the Eurozone and the importance of direct and indirect financial exposures. We use BIS cross-border direct banking flows to link member states in a GVAR framework and jointly model sectoral CDS premia. Based on balance sheet positions of an intermediate debtor country, we calculate indirect exposures and asses how the level of interconnectedness is impacted when indirect links are accounted for. We notice a general slowdown in financial integration and a reduction in cross-border assets in the hope of limiting international contagion. By differentiating between direct and indirect links, we show that the impact of reduced weights on core member states is insignificant and that deleveraging strategies are not able to successfully reduce risk.
\end{abstract}

Keywords: Financial integration; GVAR; Banking crisis; Sovereign debt crisis JEL classification: G01; G21; F34; F36

\footnotetext{
*Maastricht University, Department of Economics, PO Box 616, MD 6200, Maastricht, The Netherlands, Tel.: +31433883653; Email: a.bicu@maastrichtuniversity.nl

$\dagger$ Maastricht University, Department of Economics, PO Box 616, MD 6200, Maastricht, The Netherlands, Tel.: +31433883442; Email: b.candelon@maastrichtuniversity.nl
} 


\section{Introduction}

A recent report of the ECB on "Financial integration in Europe" from April 2012 points to the slowdown in financial integration during the sovereign debt crisis. Following the increase in risk in the Eurozone, banks are trying to significantly reduce their ties to distressed sovereigns and their ailing banks 1 Exposures to Greece and other peripheral countries have already brought significant losses for financial institutions and, through balance sheet channels fostered by cross-border banking, negative shocks have also been transmitted internationally to other sectors. The recent decline in cross-border credit activity and exposures to foreign sovereign debt has reversed some of the integration that the Single Market fostered. An important question to ask at this point is wether diminishing banking links are significantly decreasing the level of interconnectedness and are successful in eliminating risk. Are these deleveraging strategies reducing the effect of foreign shocks on the domestic economy? What is the role of globalized financial intermediaries in the transmission of shocks?

Our aim is to analyze international links and sectoral spillovers in the Eurozone arising from integrated banking systems. The paper relates to the extensive research on banking and debt crises (e.g. Reinhart and Rogoff, 2011) and to the balance sheet approach to financial crises literature (e.g. Allen et al., 2002). Based on cross-border banking data, we want to differentiate between direct and indirect exposures, i.e. balance sheet connections that are created through a third party. We believe that the aggregate risk of banks in the Eurozone is much higher than what direct asset or liability positions would imply. We expect indirect exposures to be a significant channel for risk transfer and we believe that disregarding such links would severely understate the vulnerability of a country's banking and sovereign sectors. By acknowledging these balance sheet connections we are able to better understand the channels of risk transfer during times of stress. Methodologically, our empirical analysis relies on the recent Global Vector Autoregressive (GVAR) methodology introduced by Pesaran et al. (2004). This framework allows us to jointly model sectoral Eurozone data and connect member states through links created via the balance sheets of financial intermediaries.

A key economic question during this period of increased risk and uncertainty would be whether strategies of deleveraging through balance sheet asset reduction are effective. Does moving away from risky positions insulate the domestic banks from negative shocks and, through balance sheet channels, the sovereign sector? Anticipating on our results, we find that indirect exposures are significant and that cumulated vulnerabilities of domestic banking sectors are much larger than expected. Considering the high level of interdependence across the Eurozone and the uncovered indirect balance sheet links, we find that decreasing financial exposures does not significantly reduce the effects of foreign shocks and that deleveraging strategies are not always successful in eliminating risk. We draw attention to the destabilizing role of cross-border banking: financial links between sectors and countries potentially have an important role in fostering the transmission of the crisis. The existing framework has not been able to

\footnotetext{
${ }^{1}$ Significant decreases in cross border banking claims between 2011:Q3 and 2011:Q4 had as counterparties financial institutions in Italy (\$-65 billion) and Spain ( $\$-45$ billion). Total banking sector holdings of PIIGS government debt securities also experience a strong decline between July and December 2011, with France deleveraging by $18.5 \%$ and Germany by $9.4 \%$.
} 
detect the recent buildup in vulnerabilities and, through a deficient early warning mechanism, has to some degree enabled the escalation of the crisis. Supervision appears insufficient and significant deficiencies in regulation that were not obvious during good times have now been highlighted.

This paper is organized as follows. Section 2 reviews the recent literature on sovereign and banking distress in the Eurozone. Section 3 discusses direct and indirect banking links and Section 4 presents the GVAR framework. Section 5 describes the data used. Section 6 presents the results of our baseline and counterfactual analysis, with a series of robustness checks in section 7. Section 8 concludes.

\section{Related literature}

The on-going Euro debt crisis has brought attention to the strong links between the sovereign and the banking sector, inside as well as across borders. Regarding the origin of the distress, the causality can go in both directions: from sovereign to banking through balance sheet accumulation of risky domestic and foreign country debt $2^{2}$ as well as from banking to sovereign, through a risk transfer after government bailouts (asset purchases, debt guarantees, liquidity injections) and the resulting fiscal deficits ${ }^{3}$ There is also a high level of uncertainty regarding future developments in the sovereign debt crisis, a possible systemic bank crisis and the balance sheet channels through which these shocks are transmitted across an integrated market.

The impact of banking-sovereign linkages can be evaluated and interpreted using the balance sheet approach (BSA) to financial crises approach. As summarized in Allen et al. (2002), the BSA offers a theoretical basis for the observed risk transfer. Inter-sectoral transmission channels within as well as across borders are highlighted in Rosenberg et al. (2005), with the authors pointing out that an asset for one sector is a liability for another one (domestic or foreign). In a globalized and integrated market, the "international finance multiplier" as described by Krugman (2008) highlights that distress and losses are transmitted internationally through the balance sheets of leveraged financial institutions. The paper of Ahrend and Goujard (2011) on systemic banking crises also defines a series of potential cross-border contagion effects transmitted through interconnected balance sheets of banks and other agents. They refer to "lending-country spillovers" and "common-creditor contagion shocks" to encompass possible channels of risk transfer, either directly through exposures to risky counterparts or indirectly through a reduced credit flow to other debtors respectively. Both of these last two papers identify financial institutions as the core source of interdependence between countries and markets.

There are a few empirical papers discussing the banking-sovereign connection during the on-going euro debt crisis. Studies focusing on sovereign risk, proxied by bond yields or credit default swap spreads $(C D S)$, usually find a strong connection between the size and health of the financial sector and deteriorating country specific risk measures across the Eurozone (Gerlach et al., 2010, Diekmann and Plank, 2011, Mody and Sandri, 2011 inter alia). In a study on contagion in the government debt market, Gomez-Puig and Rivero (2011) track cross-border BIS banking flows and identify dynamically the strength of causal-

\footnotetext{
${ }^{2}$ For example in the case of Greece, Italy, Spain and more recently Belgium and France.

${ }^{3}$ Ireland is the most representative.
} 
ity between pairs of countries and the determinants of contagion 4 Papers on interaction and feedback effects in between the sovereign and banking sectors identify an increasing interconnectedness resulting from government interventions and the subsequent risk transfer (Achayra et al., 2011, Alter and Schuler, 2011). All of these papers deal with the inter and intra-sectoral risk interactions on a country by country or bivariate basis and are not suited for an integrated analysis of the Eurozone. Using an extensive panel of bank and sovereign $C D S$ spreads, Ejsing and Lemke (2011) also analyze feedback effects in between the two sectors and observe a stronger comovement between banking and sovereign after the bailouts (Oct. 2008). Their estimation is however based on a strict homogeneity assumption, as the parameter capturing the strength of the relationship is not allowed to vary across countries. The paper of Bolton and Jeanne (2011) proposes a theoretical model for debt distress and contagion and take into account banking to sovereign exposures provided by the 2009 stress tests 5 Their model however only includes two countries, one safe and one risky, and cannot capture the heterogeneity and complexity characterizing the Euro debt crisis.

Significant contagion effects from distressed peripheral member states have had without a doubt an important role in the on-going crisis. Based on balance sheet exposures and investor sentiment, economies with relatively sound fundamentals have been negatively influenced by foreign shocks originating in Greece and Ireland. At the same time, bank bailouts and purchases of sovereign debt has created strong links in between the banking and sovereign sector inside country borders. Considering these complex transmission channels, one can therefore not analyze country specific data independently and disregard cross-border and inter-sectoral spillovers. The recent debt crisis has helped emphasize the central role of these links in the transmission of negative shocks. Most of the papers cited focus on one sector at a time or use bivariate systems for country specific analyses. When dealing with an integrated common currency area, such segmented approaches are inappropriate and disregard significant transmission channels and comovement properties of the data ${ }^{6}$ We would like to join countries and sectors in the Eurozone using balance sheet connections created by an integrated financial system. By modeling feedback effects inside as well as across borders we aim at joining together the inter and intra-sectoral connections highlighted in the literature.

An important contribution of our paper is the identification of direct and indirect risk factors in the balance sheets of banking institutions. To further motivate the central role of banking and inter-sectoral links, we now proceed with a more detailed description of cross-border banking in the Eurozone and with defining direct and indirect exposures.

\footnotetext{
${ }^{4}$ Significant increases in causality are interpreted as signs of contagion and a probit model is used for determining the contribution of debt (private and public) and the health of the financial system.

${ }^{5}$ The data provided by the stress tests is only partial considering that securities held until final maturity on the balance sheet were excluded from risk calculations.

${ }^{6}$ In an economic and monetary union, dynamics are mainly driven by common factors and the impact of idiosyncratic elements is significantly reduced, see for e.g. Bicu and Candelon (2011).
} 


\section{Direct and indirect banking links}

We are interested in capturing cross-border banking exposures in between Euro area member states. Since the financial system in Europe is mainly bank-based, securing around $80 \%$ of all private credit, cross-border banking flows should cover a substantial proportion of financial exposures. The strong international character of banking activity in the common currency area is a direct result of policies and regulations promoted during the last 25 years. Most notably, the first and second banking directive:7 were aimed at eliminating restrictions to cross-border banking activity, coordinating laws as well as preventing any discriminatory treatment in host countries. A direct effect of such regulations is the surge in crossborder banking activity in Europe, with the well-documented positive effects observed during the last decade (an excellent summary of cross-border banking can be found in Allen et al., 2011).

Calculations of cross-border direct exposures by Claessens et al. (2010) show that European banks have foreign assets in total of around $65 \%$ of all assets, with numbers as high as $82 \%$ for Deutsche Bank, $60 \%$ for Santander and Unicredit and $40 \%$ for BNP Paribas. Furthermore, cross-border bank flows account for around $50 \%$ of total external liabilities in the balance of payments of Belgium and around $20 \%$ for France, Italy and the Netherlands. Disaggregation of flows at sectoral level shows a significant increase in interbank lending as a proportion of total loans after the introduction of the Euro, up from $15.5 \%$ (1997) to $23.5 \%$ (2008) 8 The balance sheets of financial institutions also include significant holdings of foreign bank securities, amounting to $12.1 \%$ (1997) and 31.3\% (2008) of total assets. Banks are important buyers of government debt 9 , with a strong home bias. According to the 2009 stress tests and as calculated by Bolton and Jeanne (2011), 30\% of total Eurozone government debt is held in bank portfolios, with significantly higher numbers for Spain (55\%) and Germany (47\%). Disaggregating between foreign and domestic, the highest foreign sovereign exposures are observed in the domestic banking sector of the Netherlands (75\%), Belgium (70\%) and France (58\%).

Moving beyond the summarized direct cross-border links, we define indirect exposures as balance sheet connections through an intermediate debtor country. In a GVAR using trade links, Cesa-Bianchi et al. (2011) identify similar secondary channels and conclude that the higher synchronization in between Latin American countries and China are due to increasing trade integration of China with Latin America's major trade partners (US, Canada). Using the same intuition of Cesa-Bianchi et al. (2011), we also notice that indirect banking exposures significantly impact the degree of interconnectedness and represent a significant channel for risk transfer. In Figure 1 we elaborate on the idea of first and second round effects in the Eurozone. The diagram bellow gives an example of how a core country, e.g. Germany, can be exposed to distressed countries through third parties that have significant foreign assets in the form of claims on PIIGS ${ }^{10}$ The direction of the arrow indicates that Core has a claim on PIIGS and Germany on Core while $x$ and $y$ represent the "strength" of the exposure. In the data section, after defining country links, we will calculate the resulting indirect vulnerabilities.

\footnotetext{
${ }^{7}$ First directive $77 / 780 /$ EEC, Second directive $89 / 646 /$ EEC

${ }^{8}$ Relative to the interbank market, credit to the non-bank sector is on the other hand substantially lower.

${ }^{9}$ Banks can use debt instruments issued by any member state government as collateral when borrowing from the ECB.

${ }^{10}$ Portugal, Ireland, Italy, Greece, Spain.
} 


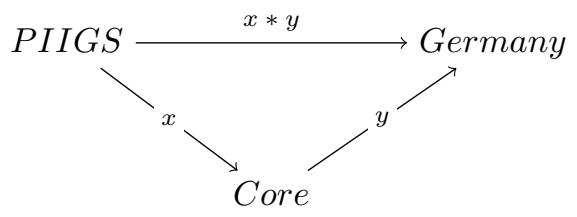

Figure 1: Indirect effects through an intermediate debtor

In a monetary union with highly integrated financial systems, the risks of cross-border banking activity become apparent. Bolton and Jeanne (2011) argue that alongside advantages of diversification and liquidity injection in foreign markets, these links also increase systemic risk as distress in one country is quickly transmitted to another. Considering the size and level of interdependence of banking sectors as well as the potentially significant indirect links, a complete and correct assessment of risk is essential. We believe that highlighting these "hidden" exposures is crucial for understanding the relative "success" of recent deleveraging strategies. Following the announcement of the European bank recapitalization plan in October 2011, a large number of banks are feeling the pressure to reach a specific capital requirement relative to risk weighted assets 11 Since meeting the $9 \%$ requirement can also be achieved by an asset reduction ${ }^{12}$ banks might become more likely to decrease balance sheet exposures especially relative to risky counterparts. The BIS and ECB already report a decrease in the level of financial integration following the start of the sovereign debt crisis. Based on the identified indirect exposures and recent patterns of deleveraging, we want to dynamically investigate how the transmission of shocks and the level of interconnectedness are influenced by a decrease in cross-border links. We expect a lower response of the domestic economy to foreign shocks. However, the effects of the desired decoupling might be significantly undermined by the strength of indirect exposures.

To evaluate the relative importance of direct and indirect links, we opt for a GVAR methodology. We now continue by briefly describing the GVAR.

\section{Methodology}

We would like to join countries and sectors across the Eurozone and model the observed interconnectedness. By jointly modeling domestic and foreign risk measures we are trying to account for the crosssectional correlation observed in the data. ${ }^{13}$ The GVAR developed by Pesaran et al. (2004) and Dees et al. (2007) is able to capture the links described in the cited literature. Furthermore, the GVAR can be used with nonstationary data and can account for possible cointegration relationships both between and within the country specific and foreign variables groups. The GVAR methodology is in this respect superior to similar approaches like factor-augmented models that require a stationary transformation of the data and therefore disregard any information on long-run properties.

\footnotetext{
${ }^{11}$ The national banking systems do not face liquidity problems, thanks to essentially unlimited cheap credit from the ECB, but rather experience a substantial capital shortage.

${ }^{12}$ The EBA discourages asset cuts due to potential destabilizing effects on credit/securities markets.

${ }^{13}$ Fig. C.23 calculates rolling window correlation for banking and sovereign risk measures.
} 
The GVAR stacks country specific VARX* $\left(p_{i}, q_{i}\right)^{14}$ structures and links them in a global model. A typical $\operatorname{VARX}^{*}(p, q)$ has the following representation:

$$
\begin{gathered}
x_{i t}=a_{i 0}+a_{i 1} t+\Phi_{i 1} x_{i, t-1}+\ldots+\Phi_{i p} x_{i, t-p}+\Lambda_{i 1} x_{i, t-1}^{*}+\ldots+\Lambda_{i q} x_{i, t-q}^{*}+u_{i t}, \\
x_{i t}^{*}=\sum_{j=1}^{n} w_{i j} x_{j t}, j \neq i,
\end{gathered}
$$

where $x_{i t}$ and $x_{i t}^{*}$ are domestic and foreign variables respectively; $w_{i j}$ captures the strength of bilateral links in between countries $i$ and $j$.

The country specific models are stacked and we obtain the (reduced form) GVAR model, where $\mathrm{r}$ is the maximum of $\left(p_{i}, q_{i}\right)$ over all countries $i$ :

$$
x_{t}=b_{0}+b_{1} t+F_{1} x_{t-1}+\ldots+F_{s} x_{t-r}+\epsilon_{t} .
$$

Most GVAR studies use trade flows when calculating the strength of bilateral links $w_{i j}$. While these are the main driver behind real sector synchronization (international business cycle), we expect financial/banking links to be more appropriate when dealing with high frequency financial data during the recent crisis. Krugman (2008) highlights the increasing importance of the "international finance multiplier" for the transmission of shocks in a globalized world economy. Our detailed description of banking activity in the Eurozone and its core role in providing liquidity also strengthens our case. Galesi and Sgherri (2009) are the first ones, to out knowledge, to consider the importance of financial/banking links in a GVAR, although their analysis follows a completely different scope and is not restricted to the Eurozone. Eickmeier and Ng (2011) carry out forecasting exercises using several weighting schemes. Using an updated version of the dataset in Dees et al. (2007), the authors conclude that FD ${ }^{15}$ flows perform the best when it comes to forecast accuracy. They also make the important distinction in between Assets and Liabilities exposures when calculating country weights. We will touch on this subject in the data section.

Following the GVAR literature, a series of preliminary analyses and specifications tests need to be performed. Besides checking stationarity and cointegration properties for the time series considered, we also need to perform a series of additional tests for all variables we want to include in our country models. One of the main assumption of the GVAR is that all foreign variables included in the VARX* are weakly exogenous. As described in Dees et al. (2007), the null of exogeneity implies that the cointegrating relationships found for a country model do not significantly enter the marginal model of any $x_{i t}^{*}$ included in that specific VARX*. We can check the validity of this assumption via an F-test, with degrees of freedom depending on the cointegrating space dimension. The exact specification of our model following the output of these specification tests will be presented in the results section.

Based on our VARX* country models, our main interest is the strength of the relationships we are trying to model. The dynamic analysis in a GVAR is performed using the Generalized Impulse Response Function (GIRF), tracking the effects of specific shocks on variables of interest. Based on Koop et al.

\footnotetext{
${ }^{14} p_{i}$ and $q_{i}$ are the lag lengths for domestic and foreign variables in country $i$

${ }^{15}$ Foreign Direct Investment.
} 
(1996) and Pesaran and Shin (1998), Appendix B describes how the GIRF are constructed. Note that the shocks are not orthogonalized and, therefore, the interpretation of the impulse responses should be made with care. While we could argue for a specific ordering of the variables included in each country model, there is no economic intuition that would justify how countries should be ordered in the GVAR. These issues have been discussed intensively in Pesaran et al. (2004) and Dees et al. (2007).

\section{Data}

\subsection{Sovereign and banking risk}

For our empirical analysis we include 10 Eurozone member states: Austria, Belgium, France, Germany, Greece, Ireland, Italy, Netherlands, Portugal and Spain. As measures of risk for the sovereign and banking sector, we follow the literature and use Credit Default Swaps with a 5 year maturity ${ }^{16}$ The BIS gives the following definition of a $C D S$ contract: "Credit default swaps are credit protection contracts whereby one party agrees, in exchange for a periodic premium, to make a contingent payment in the case of a defined credit event ${ }^{17}$ The contract implies a credit risk transfer, from the holder of the underlying security to the seller of the $C D S$ contract. Data is expressed as an yearly percentage of the notional principal that the protection buyer needs to pay the seller. This premium offers information regarding default probability of the underlying contract and can therefore be interpreted as the perceived creditworthiness of the security issuer, either a central government or bank. Our data is weekly, covering November 2008 to January 2012.

Table 1 contains the banks in the Eurozone included in our banking sector $C D S$ measures. Considering trading volume in the European credit derivative market and data availability, we have decided to use data on $C D S$ contracts with a Modified Modified Restructuring option (MM) which are based on senior debt instruments. Exact definitions and disaggregation of contracts are available in Appendix C. After collecting $C D S$ series for individual banks we can create averages for each country of interest. We can choose in between calculating simple averages and constructing weighted country wide measures of risk using total assets of each bank. Most papers using $C D S$ series for the banking sector are based on simple averages of all banks whose head-office is located in the reporting country. We believe that weighted averages are more informative regarding the aggregate state of the sector.

\footnotetext{
${ }^{16} \mathrm{CDS}$ contracts with a 5 year maturity are the most traded credit derivative products.

${ }^{17}$ http://www.bis.org/publ/qtrpdf/rqt0312g.pdf.
} 
Table 1: Banks included

\begin{tabular}{|c|c|c|c|}
\hline Bank & Country & Bank & Country \\
\hline Erste Group & Austria & Raiffeisen Zentralbank & Austria \\
\hline BAWAG P.S.K & Austria & KBC Bank & Belgium \\
\hline Dexia & Belgium & BNP Paribas & France \\
\hline Crédit Agricole & France & Credit Lyonaise & France \\
\hline Societe Generale & France & Natixis & France \\
\hline Deutsche Bank & Germany & Commerzbank & Germany \\
\hline Bayerische Landesbank & Germany & Landesbank Baden-Württemberg & Germany \\
\hline Nord Landesbank & Germany & West Landesbank & Germany \\
\hline Landesbank Berlin & Germany & DZ Bank & Germany \\
\hline IKB Deutsche Industriebank & Germany & Alpha Bank & Greece \\
\hline Eurobank EFG & Greece & Allied Irish Banks & Ireland \\
\hline Anglo Irish (up to 2011) & Ireland & Unicredit & Italy \\
\hline Intesa Sanpaolo & Italy & Banco Popolare & Italy \\
\hline Banca Monte dei Paschi di Siena & Italy & Unione di Banche Italiane & Italy \\
\hline Mediobanca & Italy & Banca Italease & Italy \\
\hline Banca Popolare Milano & Italy & ING & Netherlands \\
\hline Rabobank & Netherlands & ABN Amro & Netherlands \\
\hline SNS Bank & Netherlands & Banco Comercial Português & Portugal \\
\hline Banco Espírito Santo & Portugal & Caixa Geral de Depósitos & Portugal \\
\hline Banco Santander & Spain & BBVA & Spain \\
\hline Bankia (Caja Madrid + Bancaja) & Spain & Banco Popular Español & Spain \\
\hline Banco Sabadell & Spain & Bankinter & Spain \\
\hline La Caixa & Spain & & \\
\hline
\end{tabular}

Note: Domestic banks are those which have their head-office located in the reporting country

Although our main focus is the dynamics of domestic and foreign $C D S$ time series, we are also interested in augmenting our bivariate systems with other country specific variables capturing economic developments. Sovereign and banking $C D S$ will be jointly influenced by the stance of the economy. We choose to introduce country specific spreads as the difference in between long term bond yields and a short term interest rate 18 This variable captures the risk premium as a direct measure for country distress and contains significant information regarding present and future economic developments.

\subsection{Banking exposures}

For calculating weights, we use Table 9B "Consolidated claims - immediate borrower basis" 19 from the BIS for the period 2008:Q3-2011:Q4. This covers quarterly balance sheet positions of reporting banks, including loans, deposits, securities and derivative contracts. The stock of claims in the balance sheet

\footnotetext{
${ }^{18}$ Spread $=10$ year sovereign bond yield -1 month EURIBOR

${ }^{19}$ Allocated to the country where the original risk lies. More detailed explanations are provided in Appendix C.
} 
of a bank have as counterparty a foreign debtor in either bank, non-bank, private or public sector 20 We opt for asset side positions when calculating our weights, i.e. during a specified period $w_{i j}$ is the proportion of total claims of banking sector in country $i$ on residents of country $j, w_{i j}=\frac{C_{i j}}{\sum_{k=1}^{n} C_{i k}}$, where $n$ is the total number of countries. A more detailed discussion about interconnected balance sheets and possible risk transfers through assets and liabilities positions can be found in Appendix D. We also look at the dynamic behavior of weights and bilateral claims across our sample (2008:Q3-2011:Q4) and notice a decrease in total banking intermediation for all the countries in our sample. Considering that a decline in total claims for a country $i\left(\sum_{k=1}^{n} C_{i k}\right)$ will understate the change in $w_{i j}$, weights do not vary as much as bilateral claims $C_{i j}$ and are in general rather stable over our sample 21 The weights that we use for our GVAR analysis are fixed ${ }^{22}$ After averaging the data, we calculate for every member state in our sample the relative contribution of each debtor. Table 2 includes the banking weights calculated using cross-border claims of country $i$ (column) on country $j$ (line). Each column sums up to one.

Table 2: Cross-border banking weights

\begin{tabular}{c|cccccccccc}
\hline \hline Country & Austria & Belgium & France & Germany & Greece & Ireland & Italy & Ned & Portugal & Spain \\
\hline Austria & 0.000 & 0.022 & 0.016 & 0.085 & 0.018 & 0.030 & 0.216 & 0.015 & 0.006 & 0.019 \\
Belgium & 0.025 & 0.000 & 0.141 & 0.035 & 0.026 & 0.035 & 0.012 & 0.211 & 0.012 & 0.030 \\
France & 0.091 & 0.200 & 0.000 & 0.180 & 0.157 & 0.121 & 0.080 & 0.163 & 0.092 & 0.144 \\
Germany & 0.427 & 0.120 & 0.193 & 0.000 & 0.352 & 0.320 & 0.529 & 0.286 & 0.055 & 0.190 \\
Greece & 0.033 & 0.015 & 0.045 & 0.034 & 0.000 & 0.034 & 0.012 & 0.013 & 0.109 & 0.004 \\
Ireland & 0.042 & 0.230 & 0.041 & 0.139 & 0.070 & 0.000 & 0.036 & 0.044 & 0.239 & 0.051 \\
Italy & 0.172 & 0.124 & 0.319 & 0.160 & 0.047 & 0.208 & 0.000 & 0.094 & 0.044 & 0.154 \\
Ned & 0.129 & 0.168 & 0.095 & 0.144 & 0.294 & 0.074 & 0.049 & 0.000 & 0.125 & 0.086 \\
Portugal & 0.017 & 0.014 & 0.023 & 0.036 & 0.009 & 0.027 & 0.010 & 0.014 & 0.000 & 0.321 \\
Spain & 0.063 & 0.106 & 0.126 & 0.186 & 0.027 & 0.150 & 0.056 & 0.159 & 0.319 & 0.000 \\
\hline
\end{tabular}

Note: Proportion of claims of country $i$ (column) on country $j$ (line) in total claims of $i$ with respect to all countries in our sample.

Recent patterns and the observed decrease in banking intermediation draw our attention to future deleveraging strategies. The slowdown in financial integration is mainly directed at weak peripheral states: in the hope of insulating the economy from foreign negative shocks, core countries appear to be eliminating risky assets and generally trying to minimize real links to peripheral member states. In real terms, significant decreases in cross border claims between 2011:Q3 and 2011:Q4 had as counterparties banks in Italy ( $\$-65$ billion) and Spain (\$-45 billion). Calculations by Angeloni and Wolff (2012) based on $\mathrm{EBA}^{23}$ data show also a contraction in total holdings of PIIGS government debt securities, with banking

\footnotetext{
${ }^{20}$ Interbank lending and holdings of sovereign debt represent the major bulk of such cross-border activity, as highlighted in our description of direct banking links. These BIS claims are therefore representative for characterizing banking-sovereign connections. Disaggregated data is only available for a limited number of countries, making a more clear separation of individual inter-sectoral claims not feasible.

${ }^{21}$ Appendix $\mathrm{C}$ provides a more detailed discussion on the impact of deleveraging on weights. In Table C.10 we calculate on actual changes in flows and weighs across our sample.

${ }^{22}$ The quarterly frequency of BIS data would not allow us to use time varying weights and take advantage of the extra information captured in the dynamics of weights.

${ }^{23}$ European Banking Authority.
} 
sectors of France and Germany deleveraging by $18.5 \%$ and $9.4 \%$ respectively between July and December 2011.

A key economic question during this period of increased risk and uncertainty would be whether strategies of deleveraging through balance sheet asset reduction are effective. Does moving away from risky positions insulate the domestic banks from negative shocks and, through balance sheet channels, the sovereign sector? Before answering these questions through our dynamic analysis, we first proceed with calculating indirect exposures.

In the motivation of our paper, we have mentioned the potentially important indirect banking links. We focus on exposures of core countries to counterparties located in any of the PIIGS states. Based on the balance sheet connections described in Figure 1, we calculate cumulated (average) indirect exposures to peripheral countries through an intermediate debtor country. It is of course possible to continue this calculation using third round effects, we however expect these to be insignificant and only focus on links as described in the diagram. Table 3 summarizes total weaknesses when taking into account indirect exposures. Data is expressed in relative contributions of each PIIGS counterparty to total exposures of core member states. The percentages indicate the contribution of second round effects to cumulated vulnerabilities, e.g. $28.4 \%$ of Austria's links to Italy are resulting from indirect balance sheet exposures. Note that these calculated "weights" no longer sum up to 1.

Table 3: Cross-border banking - Total exposures and contribution of indirect exposures

\begin{tabular}{c|cc|cc|cc|cc|cc}
\hline \hline Country & \multicolumn{2}{|c}{ Austria } & \multicolumn{2}{c}{ Belgium } & \multicolumn{2}{c}{ France } & \multicolumn{2}{c}{ Germany } & \multicolumn{2}{c}{ Netherlands } \\
\hline Italy & 0.241 & $28.4 \%$ & 0.271 & $54.4 \%$ & 0.369 & $13.6 \%$ & 0.275 & $41.8 \%$ & 0.243 & $61.1 \%$ \\
Spain & 0.163 & $61.2 \%$ & 0.215 & $50.6 \%$ & 0.162 & $22.2 \%$ & 0.252 & $26.3 \%$ & 0.255 & $37.7 \%$ \\
Ireland & 0.117 & $64,0 \%$ & 0.263 & $12.7 \%$ & 0.105 & $60.9 \%$ & 0.165 & $15.5 \%$ & 0.140 & $68.4 \%$ \\
Greece & 0.054 & $38.6 \%$ & 0.031 & $52.2 \%$ & 0.056 & $18.9 \%$ & 0.048 & $28.1 \%$ & 0.034 & $60.9 \%$ \\
Portugal & 0.037 & $53.8 \%$ & 0.026 & $45.0 \%$ & 0.034 & $31.2 \%$ & 0.044 & $18.3 \%$ & 0.031 & $56.1 \%$ \\
\hline
\end{tabular}

The data reveals significant weaknesses and exposures to all PIIGS countries. A series of observations can be made. First of all, the contribution of indirect links is significant, doubling the initial cross-border bank assets relative to the original BIS data. It appears that the countries in our sample are much more interconnected than what simple bilateral weights would imply. The largest "hidden" weaknesses are identified for the banking sectors of Belgium, Austria and the Netherlands. Secondly, Italy and Spain are the countries with the largest impact on core Eurozone. This is not surprising considering the size of their banking sectors and total government debt. Considering the general small exposures as well as the size of Greece and Portugal relative to the rest of countries in Table 3, the "significant" contribution of indirect is actually of a reduced magnitude.

Having defined our data, the weights to be used as well as indirect exposures, we now move on to estimating country specific models and performing our dynamic analysis. 


\section{Results}

\subsection{Preliminary analysis}

We rely for our empirical analysis on the GVAR Toolbox 1.1 developed by Smith and Galesi (2011) and use banking weights as defined in Table 2 . We start our analysis by checking the data properties of all our time series. All sovereign and banking $C D S$ series are found to be I(1). The term spread, depending on the deterministic terms included, is mainly stationary for core countries and Spain. This is not surprising considering the relatively stable long term yields. For the remaining peripheral states, the spread is $I(1)$. We next test for cointegration in each country model. We allow for a maximum lag length of 4 and use the optimal $p$ and $q$ as suggested by the $A I C$ criterion.

Table 4: VARX lag order and cointegration properties

\begin{tabular}{ccc}
\hline \hline Country & VARX $^{*}(p, q)$ & Cointegrating space \\
\hline Austria & 2,2 & 3 \\
Belgium & 1,1 & 1 \\
France & 3,3 & 1 \\
Germany & 2,2 & 3 \\
Greece & 2,2 & 1 \\
Ireland & 2,2 & 1 \\
Italy & 4,3 & 1 \\
Netherlands & 4,2 & 3 \\
Portugal & 2,2 & 1 \\
Spain & 2,2 & 1 \\
\hline
\end{tabular}

We now continue with weak exogeneity tests. Table 5 reports $5 \%$ critical values and test statistics for all foreign variables. When adding all foreign variables in the German and French country specific model, the test rejects the null of exogeneity for the term spread. We therefore decide to leave it out in both country models. At the $5 \%$ level the $C D S_{\text {sov }}^{*}$ is also endogenous for the Portugal VARX*. We however decide to still include this variable considering the much stronger rejections of the null obtained for Germany and France. Note that finding the correct specification of each country model implies a constant updating process in between weak exogeneity, cointegration and standard residual testing. 
Table 5: Test statistics for the Null hypothesis of weak exogeneity

\begin{tabular}{cccccc}
\hline \hline Country & F-test & critical 5\% & CDS sovereign $^{*}$ & CDS $_{\text {banking }}^{*}$ & Spread $^{*}$ \\
\hline Austria & $\mathrm{F}(3,147)$ & 2.666 & 0.532 & 0.689 & 0.653 \\
Belgium & $\mathrm{F}(1,155)$ & 3.902 & 0.004 & 0.112 & 0.242 \\
France & $\mathrm{F}(1,141)$ & 3.908 & 0.023 & 0.185 & - \\
Germany & $\mathrm{F}(3,149)$ & 2.665 & 0.353 & 1.728 & - \\
Greece & $\mathrm{F}(1,149)$ & 3.904 & 0.566 & 0.227 & 0.009 \\
Ireland & $\mathrm{F}(1,149)$ & 3.904 & 3.885 & 0.714 & 0.720 \\
Italy & $\mathrm{F}(1,125)$ & 3.917 & 0.186 & 0.203 & 0.792 \\
Netherlands & $\mathrm{F}(3,129)$ & 2.675 & 0.543 & 0.422 & 2.106 \\
Portugal & $\mathrm{F}(1,149)$ & 3.905 & 0.840 & 1.098 & 4.102 \\
Spain & $\mathrm{F}(1,149)$ & 3.905 & 1.031 & 0.324 & 0.059 \\
\hline
\end{tabular}

Note: We do not include the spread for France and Germany since first round tests were significantly above the critical value.

After estimating $\operatorname{VARX}^{*}(p, q)$ models for all countries in our dataset, we still find signs of left-over heteroscedasticity in the residuals of some $C D S$ equations. The specific lines of the VECM correspond to sovereign $C D S$ for Greece and Belgium and banking $C D S$ for Ireland and Italy. Because it is not computationally tractable to use a very high lag length, we have limited our maximum lag to 4 . Since countries like Greece and Ireland have experienced extreme values and high volatility in their sovereign and banking credit default swap valuations respectively, it is not surprising that the four lags used are not enough to fully characterize their behavior.

As a model check, we report correlation coefficients for the original series (levels and first differences) and the unexplained component after the VARX* fitting. We notice that the common pattern in the data is considerably reduced after accounting for international factors, with most coefficients declining significantly. We also performed a series of structural stability tests 24 which, with a few exceptions, did not reject the hypothesis of constant parameters 25

\footnotetext{
${ }^{24}$ CUSUM statistic of Ploberger and Kramer (1992), Nyblom(1989), sequential Wald statistics etc. Detailed descriptions of these tests can be found in the User Guide of Smith and Galesi (2011)

${ }^{25}$ The CUSUM based test of Ploberger and Kramer (1992) identifies some instabilities at the $\alpha=1 \%$ confidence level for $C D S^{S}$ in the Greek country model. The heteroscedasticity-robust statistic of Nyblom (1989) also rejects at $\alpha=1 \%$ the null of stability for Greece $C D S^{S}$, as well as for Italy and Netherlands $C D S^{S}$ and Austria $C D S^{B}$.
} 
Table 6: Average cross-sectional correlation

\begin{tabular}{ccccccccc}
\hline \hline Country & CDS & Levels & Differences & Residuals & CDS & Levels & Differences & Residuals \\
\hline Austria & $\mathrm{S}$ & 0.581 & 0.542 & 0.104 & $\mathrm{~B}$ & 0.460 & 0.490 & 0.222 \\
Belgium & $\mathrm{S}$ & 0.852 & 0.606 & 0.107 & $\mathrm{~B}$ & 0.792 & 0.553 & 0.272 \\
France & $\mathrm{S}$ & 0.861 & 0.611 & 0.166 & $\mathrm{~B}$ & 0.808 & 0.607 & 0.328 \\
Germany & $\mathrm{S}$ & 0.828 & 0.540 & 0.127 & $\mathrm{~B}$ & 0.728 & 0.611 & 0.367 \\
Greece & $\mathrm{S}$ & 0.765 & 0.250 & -0.205 & $\mathrm{~B}$ & 0.774 & 0.314 & 0.097 \\
Ireland & $\mathrm{S}$ & 0.685 & 0.436 & -0.081 & $\mathrm{~B}$ & 0.330 & 0.061 & -0.251 \\
Italy & $\mathrm{S}$ & 0.849 & 0.594 & 0.011 & $\mathrm{~B}$ & 0.814 & 0.614 & 0.265 \\
Netherlands & $\mathrm{S}$ & 0.658 & 0.574 & 0.103 & $\mathrm{~B}$ & 0.704 & 0.611 & 0.325 \\
Portugal & $\mathrm{S}$ & 0.780 & 0.383 & -0.045 & $\mathrm{~B}$ & 0.738 & 0.492 & 0.280 \\
Spain & $\mathrm{S}$ & 0.777 & 0.585 & 0.030 & $\mathrm{~B}$ & 0.772 & 0.636 & 0.277 \\
\hline Note: For each country variable and VARX residuals, we report an average of all correlation coefficients with remaining countries.
\end{tabular}

After estimating each country specific VARX*, we stack all models into our GVAR and move on to our dynamic analysis. We focus on the deleveraging patterns recently observed in BIS data. Does moving away from risky positions insulate the domestic banks from negative shocks and, through balance sheet channels, the sovereign sector? As Cesa-Bianchi et al. (2011) point out, we can estimate country specific VARX* models and afterwards solve the GVAR using any weighting scheme. For each weighing scheme we obtain a different set of impulse responses. With banking sectors reducing their asset position with respect to selected countries, we would like to address the issue of decreasing weights and to understand how/if the transmission of shocks through the channels uncovered by the GVAR is impacted.

\subsection{Do deleveraging strategies decrease risk?}

According to the IMF ${ }^{26}$ inadequate capital buffers, low economic growth and the escalation of sovereign risk at the end of 2011 are intensifying the pressure on European Banks to deleverage. Based on recent trends, we have decided to decrease further the average BIS (direct) banking exposures of core Eurozone with respect to peripheral countries (PIIGS). While we observe reduced banking intermediation across all members states, the decline in cross-border lending was mainly initiated by Western Europe and is overwhelmingly aimed at distressed countries ${ }^{27}$ We would like to "exaggerate" the observed pattern and decrease by $50 \%$ the existing (average) claims on counterparties located in PIIGS countries. This is a realistic scenario, strong enough to capture recent deleveraging trends and extrapolate for following periods. With high uncertainty regarding the future of Greece as well as recent downgrading of banks in Italy and Spain 28 , we expect that the contraction in financial intermediation and asset deleveraging is likely to accelerate. The IMF ${ }^{29}$ estimates that total asset deleveraging for banks in the Eurozone will amount to $\$ 2$ trillion by 2013 .

After reducing direct banking claims to one half of their original values, we calculated the retained

\footnotetext{
${ }^{26}$ Global Financial Stability Reports from September 2011 and April 2012.

27 as highlighted in Table B.10, as well as by more recent 2012 BIS data.

${ }^{28}$ On May 14, Moody's downgraded 26 Italian banks; A few days later, a series of Spanish banks were also downgraded

${ }^{29}$ Global Financial Stability Report, April 2012 and September 2012.
} 
total exposures as percentages from initial total weights as calculated in Table 3.

Table 7: Decrease direct claims on PIIGS by 1/2, percentage of total exposures remaining

\begin{tabular}{c|ccccc}
\hline \hline Country & Austria & Belgium & France & Germany & Netherlands \\
\hline Italy & $71.2 \%$ & $84.8 \%$ & $73.5 \%$ & $82.2 \%$ & $84.4 \%$ \\
Spain & $84.4 \%$ & $83.4 \%$ & $76.2 \%$ & $77.5 \%$ & $75.1 \%$ \\
Ireland & $85.6 \%$ & $71.2 \%$ & $88.2 \%$ & $74.3 \%$ & $87.4 \%$ \\
Greece & $75.4 \%$ & $83.6 \%$ & $75.3 \%$ & $77.9 \%$ & $84.5 \%$ \\
Portugal & $81.5 \%$ & $81.3 \%$ & $78.9 \%$ & $75.0 \%$ & $82.5 \%$ \\
\hline
\end{tabular}

Note: Percentages are calculated as share of total exposures from Table 3 after reducing direct cross-border claims by $50 \%$

Table 7 shows that it is not sufficient for a country to reduce its exposures in order to isolate itself from risky counterparties. The decline in total links is very limited when taking into account the contribution of indirect exposures. From a core country's perspective it is possible to unilaterally affect only direct banking claims, since indirect ones are to a large extent decided by third parties. Taking this into consideration, cutting in half total exposures implies a much more drastic decrease in direct banking flows. In some situations, with significant indirect links, the optimal claims would need to fall bellow zero in order to ensure that total exposure is reduced by $50 \%$. We recalculate new weights using the diminished direct cross-border flows and set negative ones to zero. Since the columns of our modified matrix still need to sum up to 1, we have redistributed the left-over weight proportionately to the remaining counterparties.

Table 8: Decrease total exposures by $1 / 2$, new banking weights

\begin{tabular}{c|ccccc}
\hline \hline Country & Austria & Belgium & France & Germany & Netherlands \\
\hline Italy & 0.052 & 0.000 & 0.134 & 0.023 & 0.000 \\
Spain & 0.000 & 0.000 & 0.045 & 0.060 & 0.031 \\
Greece & 0.017 & 0.007 & 0.023 & 0.017 & 0.007 \\
Ireland & 0.000 & 0.107 & 0.007 & 0.070 & 0.000 \\
Portugal & 0.008 & 0.000 & 0.007 & 0.018 & 0.007 \\
\hline
\end{tabular}

Our counterfactual analysis implies without a doubt a severe reduction in cross-border claims to all PIIGS countries. With a few exceptions, all weights are bellow $5 \%$ and more than half are zero. This might appear drastic and even not-tractable. However, the severity of the decrease in financial links in the light of our impulse responses underlines important features regarding interdependence and risk sharing in the Eurozone.

Our main interest is understanding which strategy is most advantageous for a core country. Would a decrease in banking activity in between Germany and Italy yield stronger results than just focusing on Greece? We perform this analysis for each core country, i.e. modifying the weights $w_{i j}$ according to Table 8 for each country $i$ (Austria, Belgium, France, Germany, Netherlands) at a time. This allows us to understand the optimal strategy for different member states. We look at differences in between GIRF and their confidence bounds before and after modifying the GVAR weights. If the bounds do not overlap 
then they are significantly different from each other and we can conclude that the impact does change when decreasing weights.

We want to trace the cross-border effects of shocks to country specific risk measures. Based on the VARX* estimated coefficients and the implied dynamic multipliers we calculate responses to a unit (one standard error) shock in $C D S$ measures of peripheral states (Greece, Italy, Spain and Ireland for banking only). We also create a composite shock to the PIIGS group (Portugal, Ireland, Italy, Greece, Spain) using GDP weights. Figures A.3 to A.22 in Appendix A show the GIRF of domestic to foreign $C D S$, both for sovereign and banking sectors. The black lines trace the point estimates and $90 \%$ bootstrap confidence bounds using the original weight matrix from Table 2 while the red impulse responses are obtained using modified weights as calculated in Table 80

For sovereign to sovereign ( $\mathrm{S}$ to $\mathrm{S}$ ) shocks, Figures A.3-A.7, we first notice that all GIR are positive, implying an increased risk aversion across the Eurozone. Considering the flight-to-quality effects observed in the bond market and record low borrowing costs for Germany, we might have expected to find a negative relationship in between the foreign shock and core response. There are however some pricing differences in between the bond and CDS markets, with swaps being generally less impacted by flight-to-safety factors. Regarding the magnitude, responses are rather small, with some degree of heterogeneity when comparing all countries. The GIRF becomes insignificant after 4 weeks in a few cases (Greece to Belgium and The Netherlands). The strongest reaction to foreign shocks is exhibited by Belgium, a small open economy with a large banking sector, while German swaps exhibit the smallest changes. One of the most interesting result is that although the point estimates after reducing exposures are in fact smaller, the IR are not significantly different from each other in any country. Considering that we redistributed the remaining weight gap among core countries, our deleveraging strategy is accompanied without a doubt by increases in indirect links through stronger core interconnectedness 31 There are however a few notable examples where the responses become insignificant at specific horizons: Spain and Greece to Austria, Greece to Germany. The sovereign to banking ( $\mathrm{S}$ to B), Figures A.8-A.12, effects mimic the country patterns observed in the $\mathrm{S}$ to $\mathrm{S}$ graphs. We however obtain even larger magnitudes in most cases. Again, reducing weights does not significantly alter our results.

For banking to sovereign (B to S), Figures A.13-A.17, our results show a negative relationship for shocks originating in Spain and Italy. This is consistent with a risk transfer from banking to sovereign across borders. Achayra et al. (2011) observed such pattern after a bailout announcement, although their analysis follows the sectoral interconnectedness inside a country's borders. Considering the positive correlation and impulse responses characterizing sovereign $C D S$ spreads, the cross-border results are intuitive. We must again interpret this negative relationship with care considering that the responses are significantly different from zero for only a few weeks after the original shock. We have also traced the effect of a banking shock to foreign banking sectors, Figures A.18-A.22, but the results are in almost all cases not significant.

The observed balance sheet interconnectedness has been driven by the process of financial integration

\footnotetext{
${ }^{30}$ The new weights with respect to the remaining core countries are have also been updated and are not presented here.

${ }^{31}$ Although indirect links increase artificially, the insignificant change in impulse responses strengthens the validity of the postulated indirect channels.
} 
and liberalization of financial services across borders. Credit institutions were enabled to broaden their activity almost without limits. The transfer of risk and potential threats of cross-border exposures were however not fully taken into account when designing the framework for the "Single Market". The role of the banking sector in fostering the transmission of the crisis and the strength of spillovers across borders are much stronger than one would have anticipated. Our results show consistently that a negative shock to perceived creditworthiness is transmitted to all other member states and that risk can not be contained inside national borders. Not even aggressive deleveraging strategies are able to significantly reduce the impact of the analyzed shocks. Despite a series of other directives aimed at early interventions and risk supervision 32 , these potential problems were never fully addressed.

In the light of our results, directives aimed at monitoring large exposures 33 of credit institutions and limiting them to $25 \%$ of total funds do not appear to be sufficient. Our counterfactual analysis emphasized the importance of indirect vulnerabilities and stressed that these should also be taken into account when calculating total portfolio risk. At the same time, while the reduced exposures used in our counterfactual analysis were far bellow the $25 \%$ threshold, they where nonetheless sufficient for recreating the initial pattern of most impulse responses. It is also important to note that central government debt is exempt from these limits and given a $0 \%$ risk weight. We therefore stress that it is not possible to properly asses the strengths and vulnerabilities of banking activity without correctly pricing the risk of all relevant instruments 34

\section{Robustness checks}

We would also like to perform a series of robustness checks regarding the choice of data and sample size. Our sample covers weekly data from November 2008 up to and including January 2012. While a larger span is available for most banks and central governments, we wanted to restrict our analysis to the period around the sovereign debt crisis. We believe that the multivariate system before 2008 is governed by significantly different dynamics, as we move from a period of common behavior and low variability to one of high volatility and divergence. It is very likely that risk pricing prior to 2008 was very different and not very informative about the normal dynamics in a more mature market. Moreover, data for most banks is only available starting the beginning or mid 2008. The choice of weekly time series allows us to limit the noise relative to the use of daily data while still providing us with a substantial number of high frequency observations.

Regarding our choice of variables, we could potentially consider other measures of sovereign and banking risk. $C D S$ series are widely used in the recent literature on sovereign debt and banking distress in the Eurozone. Investors do not have to hold the underlying asset which makes the swap market very liquid. Since a $C D S$ is an extensively traded high frequency financial instrument it is subject

\footnotetext{
${ }^{32}$ Directive 92/121/EC on monitoring of large exposures as well as Directive 2006/48/EC, aimed at prudential supervision by creating buffers and imposing strict requirements for financial institutions.

${ }^{33}$ Exposures to a client above $10 \%$ of funds.

${ }^{34}$ There is a large literature on sovereign bond market dynamics in the Eurozone. Convergence of yields was misinterpreted as increased integration while actually resulting from incorrect risk pricing.
} 
without a doubt to investor sentiment and speculation and might not always fully reflect real structural problems. We can argue that, due to their speculative character, these derivative contracts have a rather destabilizing influence on the correct pricing of risk 35 CDS premia might therefore not be able to correctly assess the health of the issuing entity. While we do recognize the existing issues, we believe that these credit derivatives are informative regarding creditworthiness 36 and represent a valid measure of risk 37 Regarding the use of bond yields, we have already included a (sovereign) spread variable in our GVAR. Another valid option would be to consider ratings for both types of debt issuers. The frequency and lack of variability for many issuers are two unappealing characteristics for the purpose of our analysis. Using balance sheet positions encounters similar drawbacks: while they offer a real image of financial stability, such data is only available at a yearly frequency for the sovereign and banking sectors. This makes a real time dynamic analysis difficult. As an additional robustness check, we have also compared results using weighted and unweighted bank CDS series. Our conclusions are not affected by the choice of averaging.

Regarding cross-border banking activity as reported by the BIS, we only consider claims across the 10 largest Eurozone members ${ }^{38}$ It is also relevant to ask if the banks considered are significantly exposed to other debtors not included in our sample. This would imply that controlling for intra-Eurozone influences is not sufficient and that the importance of shocks originating in other countries may be overwhelmingly larger than any other links we are trying to capture in our empirical analysis. The transmission of risk channeled by integrated banking sectors is also at work with respect to the rest of the world: CDS premia for other countries should also be controlled for. Table 9 summarizes cross-border BIS data with respect to all major counterparties.

Table 9: Disaggregated cross-border banking

\begin{tabular}{c|cccccccccc}
\hline \hline Country & Austria & Belgium & France & Germany & Greece & Ireland & Italy & Ned & Portugal & Spain \\
\hline Europe & 91.59 & 87.48 & 60.90 & 63.80 & 90.58 & 83.17 & 88.16 & 60.61 & 76.21 & 50.75 \\
\hline Developed & 42.30 & 63.58 & 54.67 & 58.87 & 35.71 & 82.32 & 66.96 & 54.23 & 65.02 & 47.49 \\
EU-10 & 22.57 & 48.19 & 39.52 & 31.48 & 6.29 & 32.18 & 52.37 & 38.29 & 55.01 & 17.03 \\
UK & 4.40 & 10.29 & 7.90 & 16.48 & 10.26 & 47.22 & 5.93 & 10.38 & 4.66 & 28.33 \\
Developing & 49.30 & 23.90 & 6.23 & 4.93 & 54.87 & 0.84 & 21.20 & 6.37 & 11.19 & 3.25 \\
\hline World & 8.41 & 12.52 & 39.10 & 36.20 & 9.42 & 16.83 & 11.84 & 39.39 & 23.79 & 49.25 \\
\hline Developed* & 2.83 & 3.30 & 10.84 & 10.88 & 2.63 & 6.64 & 3.65 & 14.93 & 5.01 & 2.21 \\
US & 3.27 & 7.72 & 18.01 & 18.96 & 1.79 & 9.90 & 3.91 & 18.07 & 4.00 & 14.93 \\
Developing & 2.31 & 1.50 & 10.26 & 6.36 & 5.00 & 0.29 & 4.27 & 6.40 & 14.77 & 32.11 \\
\hline
\end{tabular}

First of all, disaggregated data shows that our sample covers a significant proportion of balance sheets positions. Secondly, other important counterparties are UK, US as well as developing European

\footnotetext{
${ }^{35}$ New EU regulation from Feb. 2012 is aimed at restricting "naked" CDS contracts with an underlying sovereign debt instruments.

${ }^{36}$ A large number of papers address the relationship between CDS spreads and bond yields. CDS spreads and bond yields contain, in the long run, the same information regarding the risk of the issuer. A few more recent papers identify however some important changes in the information structure of the CDS market after the crisis.

${ }^{37} \mathrm{CDS}$ spreads are less sensitive to factors relatively unrelated to default risk, e.g. flight-to-quality effects.

${ }^{38}$ Cumulated GDP of sample countries represent $96 \%$ of aggregate size of Eurozone and $68 \%$ of the EU in 2010 .
} 
countries (mainly Eastern Europe). We look at the behavior of corresponding UK and US time series in order to trace potential causal links that our application disregards. Figure 2 plots sovereign and banking CDS spreads for these two countries alongside PIIGS and an average of core member states ${ }^{39}$ The UK and US risk measures do not show significant increases that might trigger the strong observed reaction in peripheral Europe. The movements in PIIGS spreads are much larger and have been consistently identified in the recent literature as the main source of distress. We believe that for the purpose of our analysis shocks outside the Eurozone are not important and that the origin of possible disturbances is correctly assigned in our empirical application.
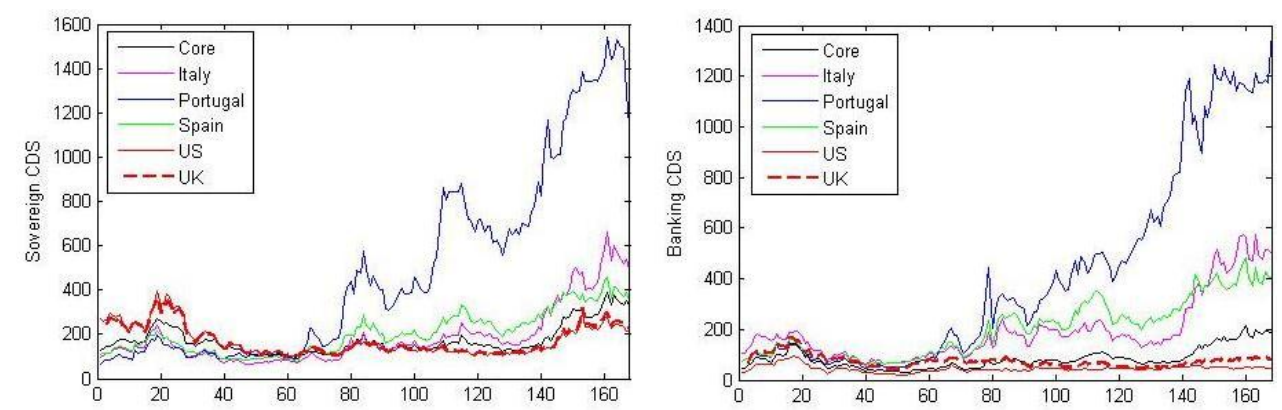

Figure 2: Banking and Sovereign CDS for the Eurozone, US and UK

\section{Conclusions}

The on-going Eurozone debt crisis has created strong links in between the sovereign and banking sectors, inside as well as across borders. The first signs of distress in the region were banking problems due to either international exposures to the US subprime crisis or the burst of domestic housing bubbles. Shortly after, revelations about Greece and its fiscal situation as well as concerns regarding other distressed member states helped fuel negative expectations and start the sovereign debt crisis. A significant number of papers have addressed the issue of country risk in the context of a monetary union and the transmission of sovereign distress through real and contagion channels. The interconnectedness in between sovereign and banking sectors has also become very strong, with causal links running in both directions. The observed feedback effects are not surprising considering the important bail-out funds used by governments and massive purchases of sovereign debt.

The aim of our paper was to jointly model banking and sovereign distress in the Eurozone using the GVAR methodology. Based on banking sector links and balance sheet exposures we find significant spillovers in between sovereign and banking distress measures, inside the country but also across borders. Usually an increase in $C D S$ spread in one country is followed by worsening borrowing conditions in between sector and across countries. There are some examples where the response has an opposite sign relative to the initial shock, indicating a risk transfer from banking to governments. This pattern has been observed by a series of authors (Achayra et al. (2011) inter alia) and can be explained by the government's perceived status of ultimate insurer.

\footnotetext{
${ }^{39}$ With a strong common behavior, the average is a representative measure for behavior in core countries.
} 
Taking into account the recent deleveraging strategy of countries in the hope of insulating the domestic economy, we have performed a series of counterfactual analyses by decreasing financial links. We started by calculating direct and indirect exposures and observed that the total exposure of core member states to distressed economies is much larger than what direct credit flows and purchases of debt securities would imply. In the light of these findings, we find that not even substantially decreasing direct exposures is sufficient to insulate the domestic economy from negative foreign shocks. The impulse responses using initial and modified weighting matrices are in most cases not significantly different from each other. The indirect transmission channels fostered by cross-border banking activity are, therefore, much more important than one would expect.

Our findings contribute to the literature of financial integration in a monetary union as well as the on-going policy debate aimed at improving the supervision and regulation of cross-border activity. The destabilizing role of banking institutions and weaknesses in regulation have been highlighted by the on-going crisis. Within the current institutional setting of the Eurozone, our empirical analysis indicates that negative shocks to sovereign and banking borrowing costs are transmitted through extensive balance sheet channels in between sectors as well as to all other member states. With most Eurozone members in a downturn phase of the economy, diversification of the banking sector and high levels of financial integration fail to achieve the positive effects observed during periods of economic growth 40 The banking sector appears instead to foster the transmission of the crisis through direct and indirect channels and exposures. Considering that the supervisory authorities were unable to identify in real time the increasing vulnerabilities of banking institutions, the existing framework for risk-assessment appears to be inadequate. In times of financial stress when discussions about "too-connected-to-fail" institutions are at the core of policy debates, the implications of our results are particularly dire.

We are not arguing for less integration, but rather for a correct and complete risk assessment. We would also like to stress the importance of banking distress early warning systems based on a common framework and cooperation in between all member states of the Eurozone. In order to address the weaknesses uncovered by recent developments in the financial and sovereign debt markets, there is an on-going discussion about crisis management 41 and a new European supervisory framework 42 Creating more appropriate regulation is without a doubt extremely difficult, as it implies a constant updating and fine-tuning of existing arrangements. Simply setting strict rules and limiting exposures to arbitrary numbers cannot guarantee the healthy functioning of financial institutions and, through the lender of last resort quality, of the government. It is also crucial to distinguish between the risk of sovereigns and banks and to limit the ensuing differentiation in country specific credit conditions that is hindering economic recovery. 43

\footnotetext{
${ }^{40}$ e.g. better credit conditions, availability of funds independent of idiosyncratic market characteristics.

${ }^{41}$ European Commission COM(2010).

${ }^{42} \mathrm{~A}$ series of macro and micro supervisory authorities have been created, inter alia the European Systemic Risk Board (ERSB) and European Banking Authority (EBA).

${ }^{43}$ The crisis related divergence in credit/deposit interest rates is heavily related to country fundamentals and does not always reflect the risk of individuals, either firms or households. Stricter credit conditions in the periphery are detrimental for investment, consumption and GDP growth.
} 


\section{Appendix A}

$\mathbf{S}$ to $\mathbf{S}$ : Response of core sovereign CDS to a one standard error shock to PIIGS sovereign CDS
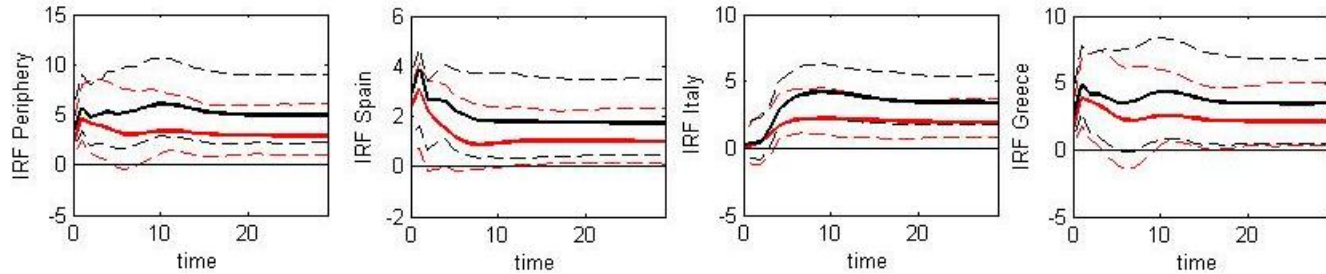

Figure 3: Austria
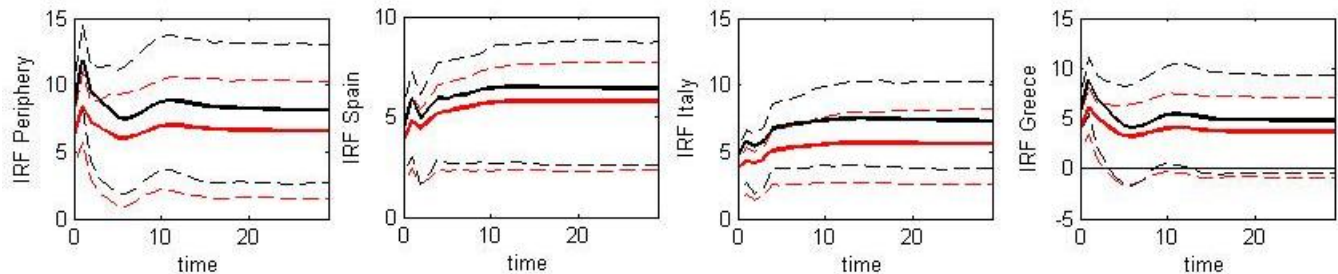

Figure 4: Belgium
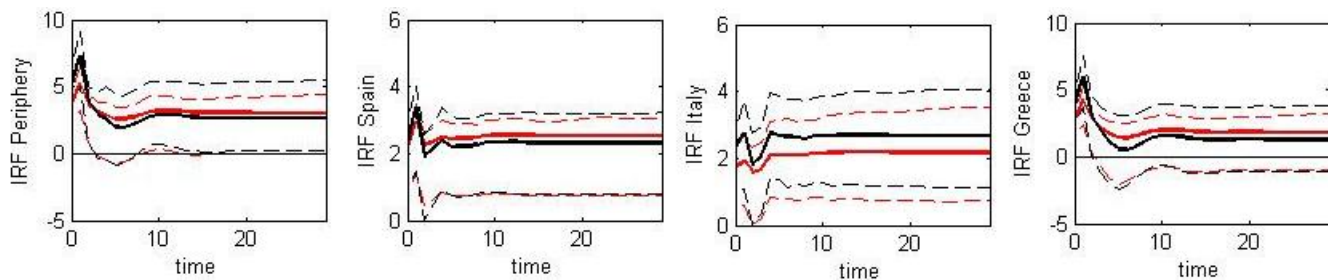

Figure 5: France
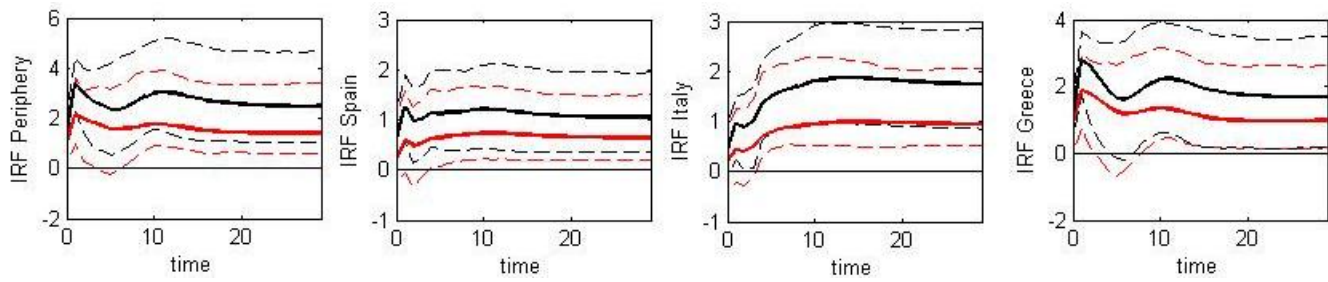

Figure 6: Germany
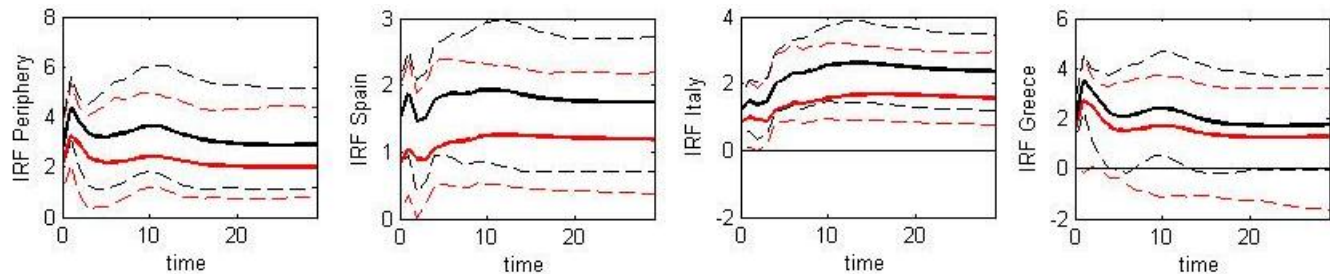

Figure 7: Netherlands 
S to B: Response of core sovereign CDS to a one standard error shock to PIIGS banking CDS
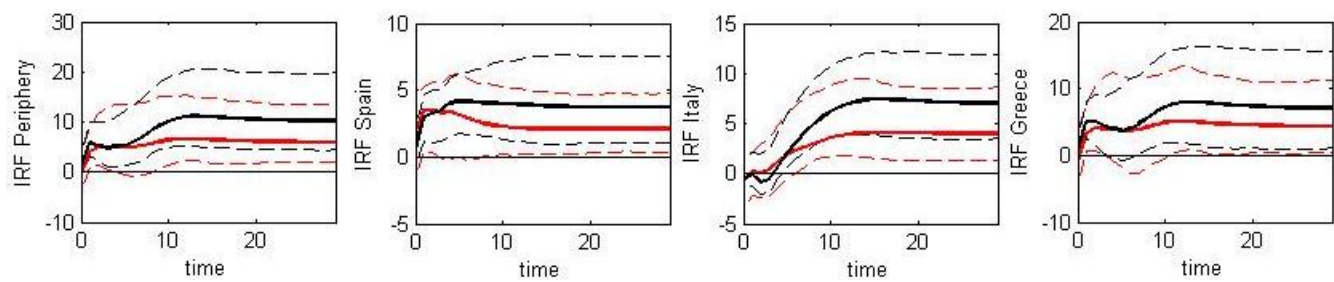

Figure 8: Austria
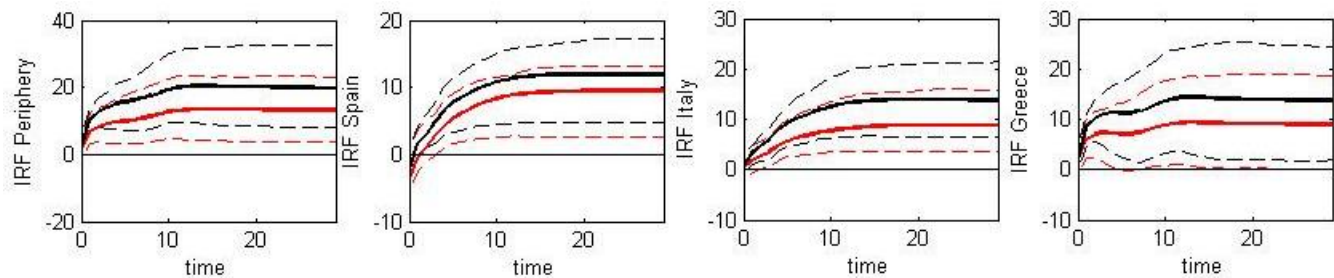

Figure 9: Belgium
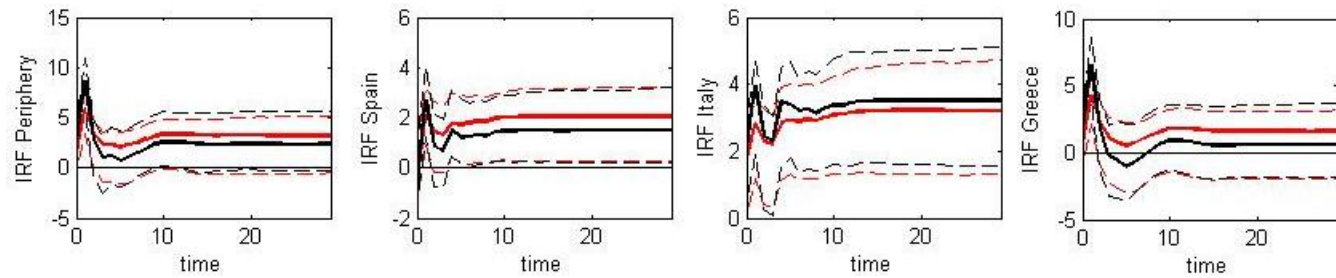

Figure 10: France
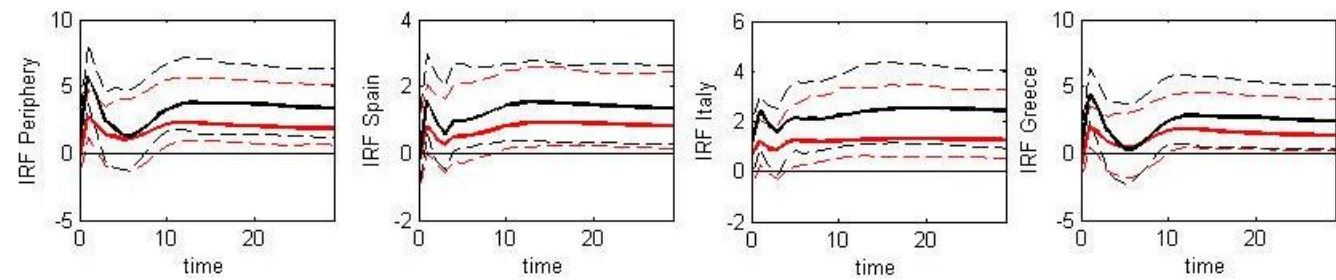

Figure 11: Germany
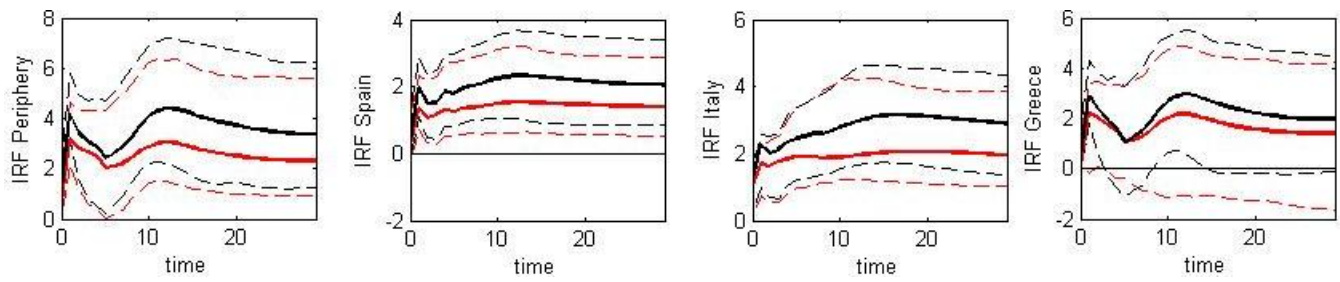

Figure 12: Netherlands 
B to S: Response of core banking CDS to a one standard error shock to PIIGS sovereign CDS
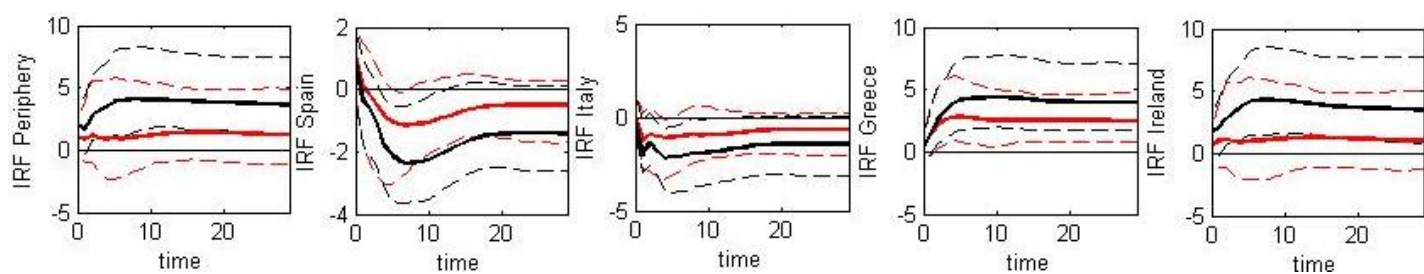

Figure 13: Austria
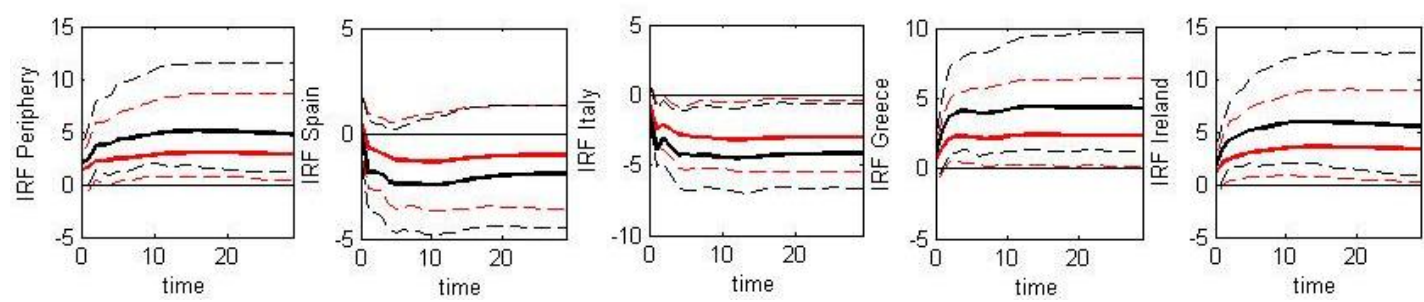

Figure 14: Belgium
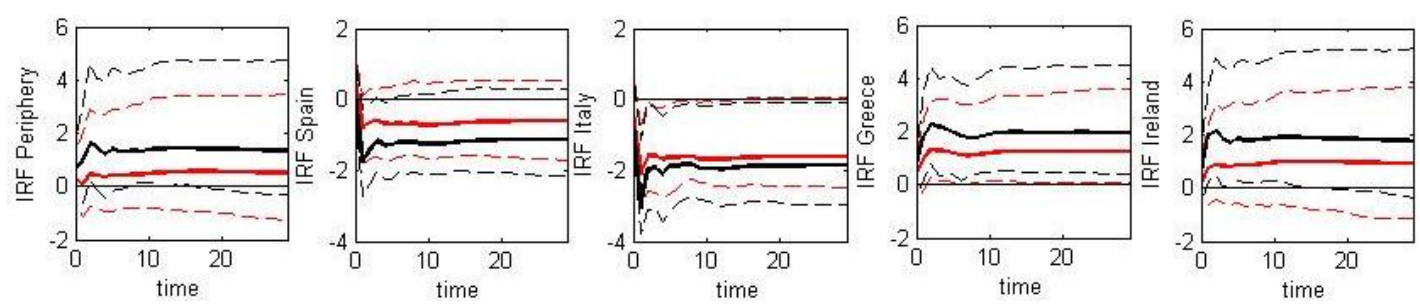

Figure 15: France
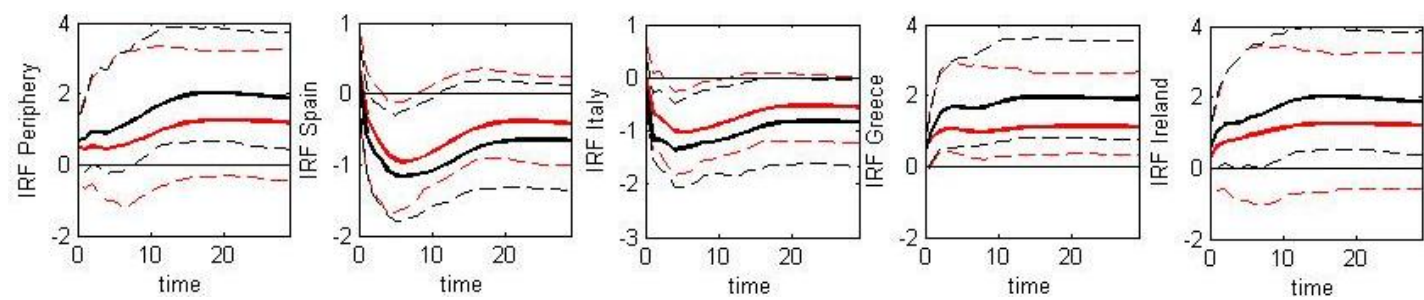

Figure 16: Germany
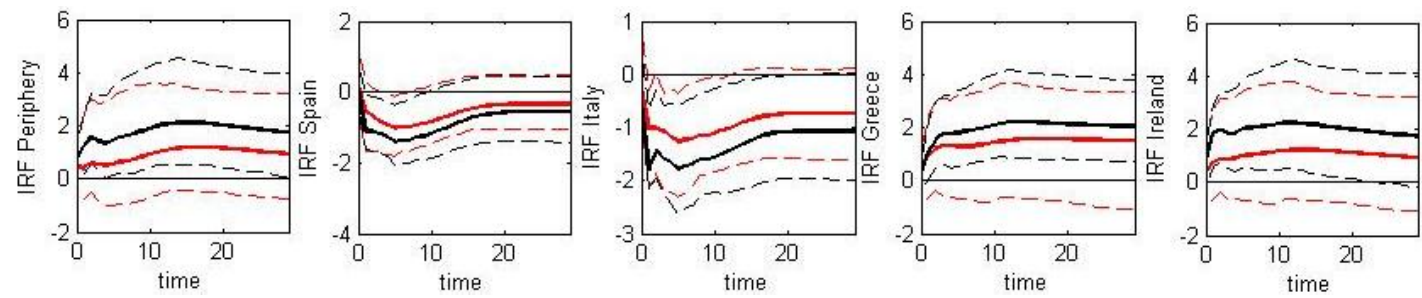

Figure 17: Netherlands 
B to B: Response of core banking CDS to a one standard error shock to PIIGS banking CDS
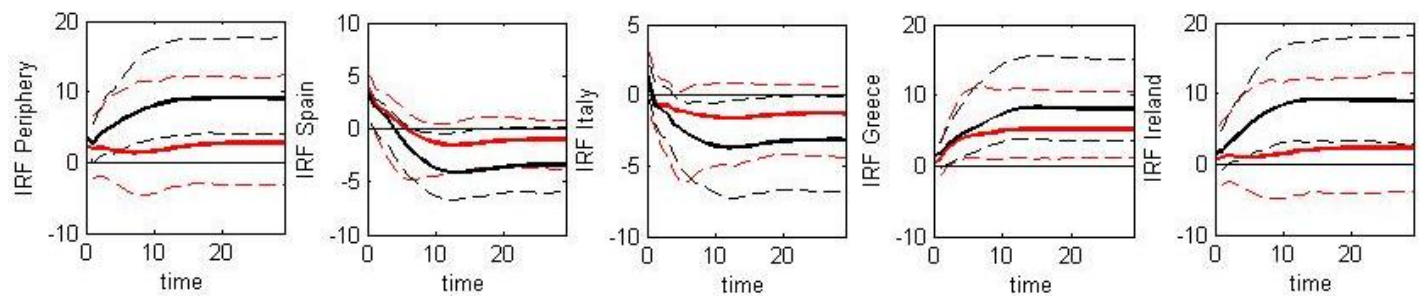

Figure 18: Austria
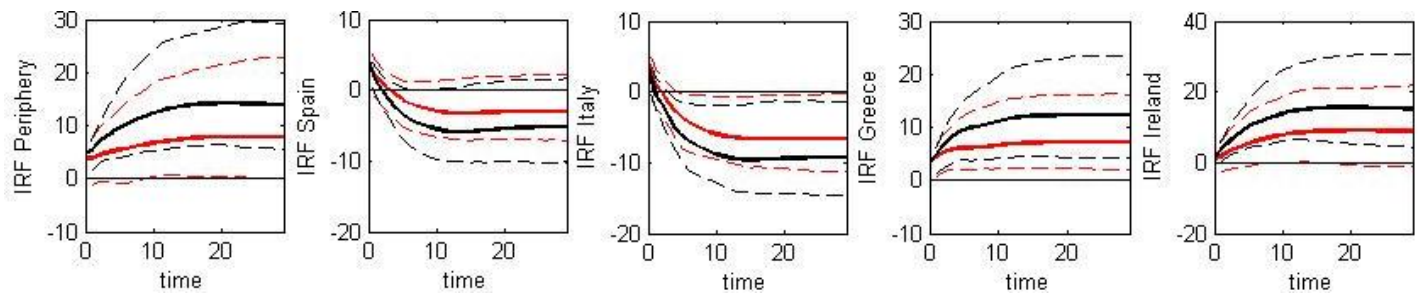

Figure 19: Belgium
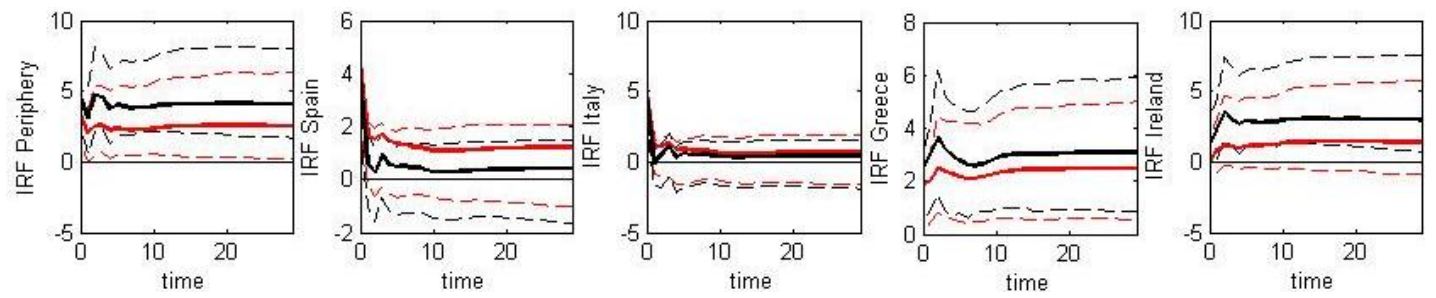

Figure 20: France
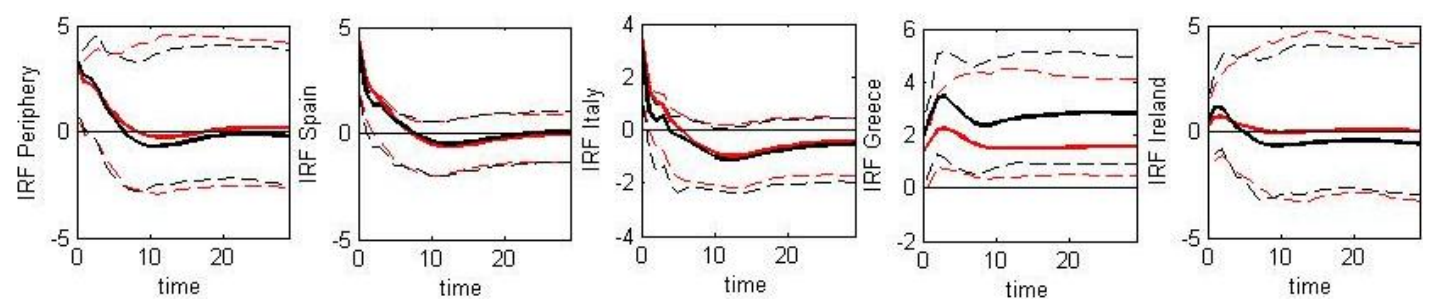

Figure 21: Germany
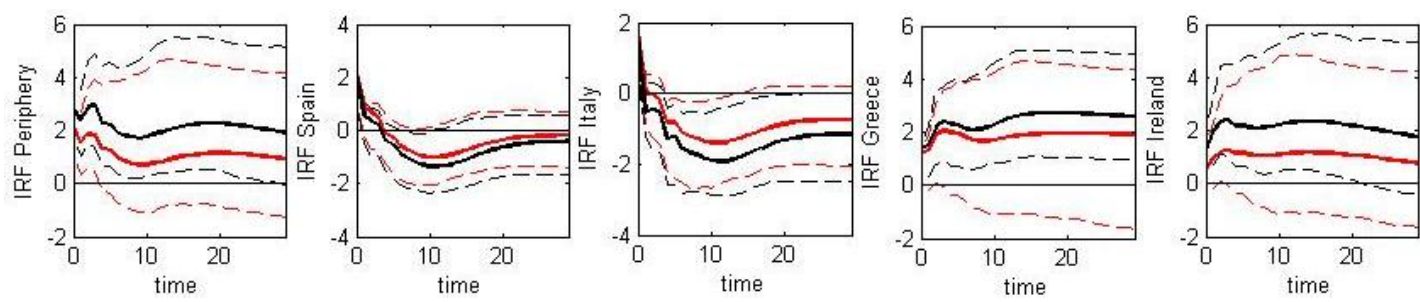

Figure 22: Netherlands 


\section{Appendix B: Generalized Impulse Responses}

In a simple $\operatorname{VAR}(p)$ setting with $\mathrm{n}$ variables and $\epsilon$ as the reduced form residuals, the response of a shock of size $\sqrt{\sigma_{i i}}$ at time t to the $i^{\text {th }}$ equation after $n$ periods is expressed in the following conditional expectation form:

$$
\operatorname{GIRF}\left(n, \epsilon_{i t}=\sqrt{\sigma_{i i}}, \Omega_{t-1}\right)=E\left[Y_{t+n} \mid \epsilon_{i t}=\sqrt{\sigma_{i i}}, \Omega_{t-1}\right]-E\left[Y_{t+n} \mid \Omega_{t-1}\right]
$$

In this setting, $\Omega_{t-1}$ is the information set available up to time $t-1$. Taking into account the correlation structure in the residuals and assuming a multivariate normal distribution, a shock of size $\sqrt{\sigma_{i i}}$ to the $i^{\prime} t h$ innovation also creates changes in all other innovations. Disregarding again any country index, in the same $\operatorname{VAR}(p)$ setting we have the following set of shocks:

$$
E\left[\epsilon_{t} \mid \epsilon_{i t}=\sqrt{\sigma_{i i}}\right]=\left(\sigma_{1 i}, \sigma_{2 i}, \ldots, \sigma_{n i}\right)^{\prime} \sqrt{\sigma_{i i}}=\Sigma e_{i} \cdot \sqrt{\sigma_{i i}}
$$

Since we are modeling systems of $\mathrm{I}(1)$ variables containing stochastic trends, some shocks $(n-r)$ will have permanent effects. We therefore expect the GIRF to tend to a non-zero constant. The response of a one standard error shock at time $t$ to the $l^{t h}$ equation on the $j^{\text {th }}$ variable at $t+n$ is the $j^{t h}$ element of:

$$
\operatorname{GIRF}\left(n, u_{i t}, \Omega_{t-1}\right)=\frac{e_{j}^{\prime} A_{n} G_{0}^{-1} \Sigma_{u} e_{l}}{\sqrt{e_{l}^{\prime} \Sigma_{u} e_{l}}}
$$

The $A_{n}$ represent the dynamic multipliers obtained recursively form the GVAR representation and $e_{l}$ is a vector that assigns the shock to the the $l^{\text {th }}$ equation. element

\section{Appendix C: Data description and definitions}

\section{C.1: Data and sources}

\begin{tabular}{ccc}
\hline \hline Variable & Name & Source \\
\hline Sovereign risk & $C D S$ sovereign & Datastream \\
Banking risk & $C D S$ banking & Datastream \\
Cross-border exposures & Banking claims & BIS \\
Bank size & Bank assets & Stress tests \\
Long interest rate & 10 year bond yield & Datastream \\
Short interest rate & EURIBOR & Datastream \\
\hline
\end{tabular}

\section{C.2: CDS underlying debt contract and restructuring clause (definitions from ISDA ${ }^{44}$ )}

A sovereign $C D S$ contract represents protection against the inability of a government to repay its debt obligations, offering a direct valuation of default risk. Similar to the sovereign case, the premium paid on bank $C D S$ contracts quantifies the perceived health and stability of the issuer. The underlying

\footnotetext{
${ }^{44}$ International Swaps and Derivatives Association
} 
debt instruments issued by the banking sector are disaggregated according to their level of subordination while the $C D S$ contract is also differentiated based on the restructuring clause specified.

Senior Debt $=$ Debt that is repayed first.

Subordinated Debt $=$ Debt repayed after senior debt has been serviced; more risky.

No restructuring $(\mathrm{NR})=$ Excludes the restructuring option, eliminating the possibility that the protection buyer suffers a "soft" credit event, i.e. not resulting necessarily in losses for the protection buyer.

Full Restructuring = Allows the buyer to deliver bonds of any maturity after restructuring of debt in any form occurs.

Modified Restructuring $=$ Deliverable obligations are limited to bonds with maturity of less than 30 months after a restructuring; popular in North America.

Modified Modified Restructuring = Deliverable obligations are limited to bonds with maturity of less than 60 months after a restructuring; popular in Europe.

\section{C.3: BIS consolidated claims}

The BIS consolidated banking statistics are based on the nationality of the reporting bank and net out intragroup positions. Domestic banks are those which have their head-office located in the reporting country BIS claims on an immediate borrower basis are allocated to the country where the original risk lies. This type of claims bypasses any other third parties that might either extend guarantees or enter hedge strategies with the debtor country or whose securities are being used as collateral. For monitoring transfer risk exposures, the most appropriate data are those on an immediate borrower basis. BIS defines foreign claims as international claims plus local claims in local currency booked by foreign affiliates.

\section{C.4: Weights and deleveraging}

Table 10: Percentage change for claims and weights between 2011:Q3 and 2008:Q3

\begin{tabular}{c|cccccccccc}
\hline \hline Country & Austria & \multicolumn{3}{c}{ Belgium } & \multicolumn{3}{c}{ France } & \multicolumn{3}{c}{ Germany } \\
\hline & Claims & Weights & Claims & Weights & Claims & Weights & Claims & Weights & Claims & Weights \\
Austria & - & - & -55.01 & 30.34 & -36.96 & -26.98 & -26.54 & 5.79 & -2.05 & 31.38 \\
Belgium & -34.13 & -17.10 & - & - & 98.55 & 129.99 & -29.91 & 0.94 & -9.66 & 21.17 \\
France & -17.90 & 3.32 & -59.47 & 22.31 & - & - & -6.91 & 34.07 & -34.59 & -12.25 \\
Germany & -17.76 & 3.5 & -79.80 & -33.27 & -14.41 & -0.86 & - & - & 6.65 & 43.07 \\
Greece & -56.30 & -45.00 & -92.55 & -66.89 & -46.36 & -37.86 & -12.50 & 26.03 & -75.81 & -67.55 \\
Ireland & -69.88 & -62.09 & -63.24 & 27.03 & -67.04 & -61.82 & -55.23 & -35.52 & -52.26 & -35.96 \\
Italy & 3.39 & 30.12 & -57.19 & 18.34 & -21.69 & -9.28 & -38.03 & -10.75 & -47.74 & -29.90 \\
Ned & -7.89 & 15.92 & -90.63 & -30.52 & 4.83 & 21.43 & -6.62 & 34.49 & - & - \\
Portugal & -60.77 & -50.62 & -85.63 & -61.29 & -17.15 & -4.03 & -37.33 & -9.73 & -61.10 & -47.82 \\
Spain & -31.91 & -14.39 & -60.31 & 10.10 & -25.48 & -13.67 & -42.55 & -17.25 & -46.28 & -27.93 \\
\hline
\end{tabular}

Considering that weights are calculated as a ratio between bilateral claims and total claims, we would 
like to look closer at their dynamics during our sample (2008:Q3-2011:Q4). We define the percentage change in bilateral weights between countries $i$ and $j$ as $\frac{w_{i j, t}-w_{i j, t-1}}{w_{i j, t-1}}=\frac{\frac{C_{i j, t}}{\sum_{k=1}^{n} C_{i k, t}-\frac{C_{i j, t-1}}{\sum_{k=1}^{n} C_{i k, t-1}}}}{\frac{C_{i j, t-1}}{\sum_{k=1}^{n} C_{i k, t-1}}}$, where $w_{i j, t-1}$ and $w_{i j, t}$ are the starting and ending weights respectively. The behavior of the ratio $w_{i j, t}$ is affected by both numerator and denominator, with the weight reflecting changes in both bilateral $\left(C_{i j, t}\right)$ and total claims $\left(\sum_{k=1}^{n} C_{i k, t}\right)$. How is a decrease in total claims affecting the dynamics of the weight? After some algebra, the percentage change in weight is simplified to $\frac{C_{i j, t} \sum_{k=1}^{n} C_{i k, t-1}}{C_{i j, t-1} \sum_{k=1}^{n} C_{i k, t}}-1$. $\frac{\sum_{k=1}^{n} C_{i k, t-1}}{\sum_{k=1}^{n} C_{i k, t}}$ represents the contribution of the change in total claims, while $\frac{C_{i j, t}}{C_{i j, t-1}}$ reflect the change in the bilateral cross-border links. Considering that, for all countries, total cross-border activity has decreased, $\frac{\sum_{k=1}^{n} C_{i k, t-1}}{\sum_{k=1}^{n} C_{i k, t}}$ will be larger than one and, hence, $\frac{C_{i j, t} \sum_{k=1}^{n} C_{i k, t-1}}{C_{i j, t-1} \sum_{k=1}^{n} C_{i k, t}}-1$ will be larger than $\frac{C_{i j, t}}{C_{i j, t-1}}-1$. Since most changes in weights are negative, this implies a less severe decrease in weights relative to actual bilateral claims. Table 10 confirms that the decline in weights is much less substantial than change in bilateral BIS data and that weights are relatively more stable in comparison to $C_{i j}$.

\section{C.5: Correlation between banking and sovereign CDS}
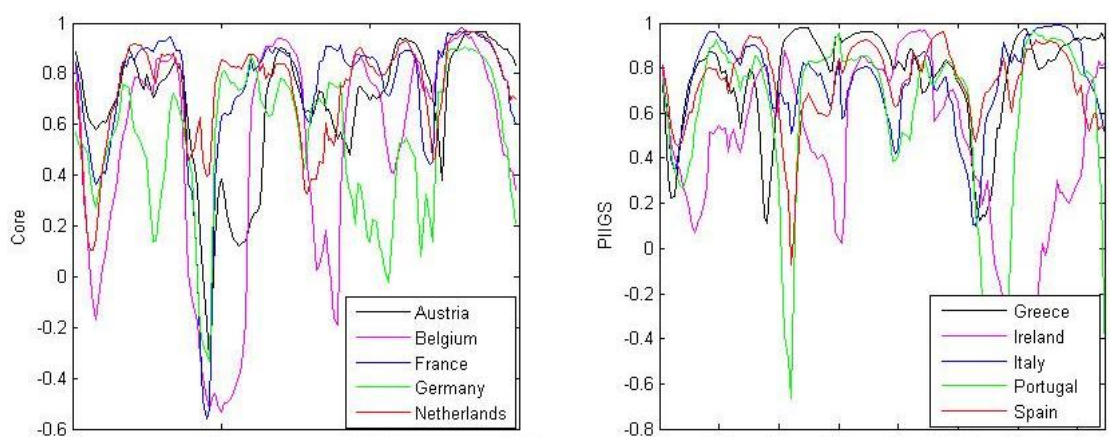

Figure 23: Dynamic correlation coefficients between sovereign and banking CDS spreads. The coefficients are based on a rolling window of CDS series over the past 20 consecutive weeks. The (lagged) correlations shown correspond to March 2009 up to Jan. 2012.

\section{Appendix D: Asset vs. Liabilities for BIS data}

Should one use claims on a counterparty or obligations towards a creditor? As we already mentioned, the BIS data covers banking data with respect to foreign entities in any sector. Since our data includes banking and sovereign $C D S$, we are limiting our interest to these two sectors. Considering that interbank lending and sovereign debt purchases account for most of the cross-border flows, other balance sheet positions should represent a limited fraction of BIS data. We simulate a negative shock to bank/sovereign risk in peripheral countries and would like to trace its impact on other countries when balance sheet exposures are taken into account. We describe a simple model that can help understand how to proceed.

Consider a three country $(C=$ core, $P=$ periphery, $O=$ other) two sector model ( $S=$ sovereign and $B=$ banking). The model can be easily extended to include more countries and sectors, mimicking more 
closely our Eurozone sample. There are two contracts being traded, credit default swap $(C D S)$ for $S$ and for $B$ in each country, denoted by $C D S$ sector country. Based on Asset $(A)$ and Liabilities $(L)$ banking exposures and using a VARX*/GVAR setting we would like to calculate the effect of a negative periphery shock $\left(C D S S_{P}\right.$ and $\left.C D S B_{P}\right)$ to $C D S S_{C}$ and $C D S B_{C}$. On the $A$ side, a component of the weight matrix $w_{P C}$ represents the proportion of total claims of $P$ banks that are held by residents in $C$. On the $L$ side, $w_{P C}$ is the amount of total debt of $P$ banks that is due to all sectors in $C$. Weights for a country sum up to 1 , i.e. $w_{C P}+w_{C O}=1$. The connection created in between the balance sheets of the two countries of interest can be expressed using the following 4 examples, with the appropriate weighting scheme in parenthesis.

[1.] $B_{P}$ owes money to $\mathrm{C}, B_{C}+S_{C}\left(\mathrm{~L}: w_{P C}\right)$. $B_{C}$ owes money to $\mathrm{P}, B_{P}+S_{P}\left(\mathrm{~L}: w_{C P}\right)$. $B_{P}$ lends money to $\mathrm{C}, B_{C}+S_{C}\left(\mathrm{~A}: w_{P C}\right)$. $B_{C}$ lends money to $\mathrm{P}, B_{C}+S_{C}\left(\mathrm{~A}: w_{C P}\right)$.

We can see that the situations where $C$ can be negatively influenced are those where significant claims on $P$ could potentially not be recovered. These are represented by cases 1 and 4 . Disregarding the time subscript and any deterministic terms we have the following VARX* for banking and sovereign $C D S$ :

$$
\begin{aligned}
C D S B_{C}= & \alpha_{1} C D S S_{C}+\alpha_{2} C D S B_{C}^{*}+\alpha_{3} C D S S_{C}^{*}+u_{C 1}=\alpha_{1} C D S S_{C}+\alpha_{4} w_{C P} C D S B_{P} \\
& +\alpha_{5} w_{C O} C D S B_{O}+\alpha_{6} w_{C P} C D S S_{P}+\alpha_{7} w_{C O} C D S S_{P}+u_{C 1} \\
C D S S_{C}= & \beta_{1} C D S B_{C}+\beta_{2} C D S B_{C}^{*}+\beta_{3} C D S S_{C}^{*}+u_{C 2}=\beta_{1} C D S S_{C}+\beta_{4} w_{C P} C D S B_{P} \\
& +\beta_{5} w_{C O} C D S B_{O}+\beta_{6} w_{C P} C D S S_{P}+\beta_{7} w_{C O} C D S S_{P}+u_{C 2}
\end{aligned}
$$

We notice that foreign $C D S$ enter the dynamics of $C D S S_{C}$ and $C D S B_{B}$ through the elements $w_{C P} C D S B_{P}$ and $w_{C P} C D S S_{P}$. A significant impact of periphery through balance sheet weaknesses is consistent with an asset side wight matrix, as exemplified by case 4 . 


\section{References}

[3] Acharya, V., Drechsler, I., Schnabl, P., 2011. A Pyrrhic victory? - Bank Bailouts and Sovereign Credit Risk. Working Paper, NBER.

[2] Ahrend, R., Goujard, A., 2011. Drivers of systemic banking crises: the role of bank-balance-sheet contagion and financial account structure. Working Paper, OECD.

[3] Allen, F., Beck, T., Carletti, E., Lane, P.L., Schoenmaker, D., Wagner W., 2011. Cross-Border Banking in Europe: Implications for Financial Stability and Macroeconomic Policies. CEPR report.

[4] Allen, M., Rosenberg, C., Keller,C., Setser, B., Roubini, N., 2000. A Balance Sheet Approach to Financial Crisis. Working paper, IMF.

[5] Alter, A., Schuler, Y. S., 2011. Credit Spread Interdependencies of European States and Banks during the Financial Crisis. Working Paper, University of Konstanz.

[6] Angeloni, C, Wolff, G.B., 2012. Are banks affected by their holdings of government debt? Working paper, Bruegel.

[7] Bicu, A., Candelon, B., 2011. Government bond market dynamics and sovereign risk: systemic or diosyncratic? Working Paper, Maastricht University.

[8] Bolton, P., Jeanne, O., 2011. Sovereign Default Risk and Bank Fragility in Financially Integrated Economies. Working Paper, NBER.

[9] Cesa-Bianchi, A., Pesaran, M. H, Rebucci, A., Xu, T., 2011. China's emergence in the world economy and business cycles in Latin America. Working paper, Cambridge University.

[10] Dees, S., di Mauro, F., Pesaran, M. H., Smith, L. V., 2007. Exploring the international linkages of the euro area: a global VAR analysis. Journal of Applied Econometrics 22, 1-38.

[11] Dieckmann, S., Plank, T., 2011. Default risk of advanced economies: An empirical analysis of Credit Default Swaps during the financial crisis. Review of Finance 16, 1-32.

[12] ECB, 2012. Financial Integration in Europe. ECB annual report.

[13] Eickmeier, S., Ng, T., 2011. How do credit supply shocks propagate internationally? Discussion paper, CEPR.

[14] Ejsing, J. W., Lemke, W., 2011. The Janus-headed salvation: Sovereign and bank credit risk premia during 2008-2009. Economics Letters 110, 28-31.

[15] Galesi, A., Sgherri, S., 2009. Regional financial spillovers across Europe: A Global VAR analysis. Working paper, IMF.

[16] Gerlach, S., Schulz, A., Wolff, G. B., 2010. Banking and sovereign risk in the euro area. Discussion paper, Deutsche Bundesbank. 
[17] Koop, G., Pesaran, M.H., Potter, S.M., 1996. Impulse response analysis in nonlinear multivariate models. Journal of Econometrics 74, 119-147.

[18] Krugman, P., 2008. The international finance multiplier. Mimeo, Princeton University.

[19] Mody, A., Sandri, D., 2011. The Eurozone crisis: how banks and sovereigns came to be joined at the hip. Working paper, IMF.

[20] Nyblom, J., 1989. Testing for the constancy of parameters over time. Journal of the American Statistical Association 84, 223-230.

[21] Pesaran, M.H., Schuermann, T., Weiner, S.M., 2004. Modelling regional interdependencies using a global error correcting macroeconometric model. Journal of Business and Economic Statistics 22, 129-162.

[22] Pesaran, M.H., Shin, Y., 1998. Generalized Impulse Response analysis in linear multivariate models. Economics Letters 58, 17-29.

[23] Ploberger, W., Kramer, W., 1992. The CUSUM test with OLS residuals. Econometrica 60, 271-286.

[24] Puig-Gomez, M., Rivero, S. S., 2011. Causality and Contagion in Peripheral EMU Public Debt Markets: A Dynamic Approach. Working paper, Complutense University. 2011/16

[25] Reinhart, C., Rogoff, K., 2011. From financial crash to debt crisis. American Economic Review 101, 16761706.

[26] Rosenberg, C., Halikias, I., House, B., Keller, C., Nystedt, J., Pitt, A., Setser, B., 2005. Debt-Related Vulnerabilities and Financial Crises, Occasional Paper, IMF.

[27] Smith, L.V., Galesi, A., 2011. GVAR Toolbox 1.1, www.cfap.jbs.cam.ac.uk/research/ gvartoolbox. 